\title{
Late Eocene impact-induced climate and hydrological changes: Evidence from the Massignano global stratotype section and point (central Italy)
}

\author{
Rodolfo Coccioni* \\ Fabrizio Frontalini \\ Dipartimento di Scienze dell'Uomo, dell'Ambiente e della Natura, Università degli Studi di Urbino “Carlo Bo,” \\ Campus Scientifico, Località Crocicchia, 61029 Urbino, Italy \\ Silvia Spezzaferri \\ Department of Geosciences, University of Fribourg, Chemin du Musée 6, Pérolles CH-1700, Fribourg, Switzerland
}

\begin{abstract}
The Eocene-Oligocene transition marks the passage from "greenhouse" conditions to an "icehouse state" with progressive global cooling starting in the early middle Eocene. The late Eocene is also characterized by a high concentration of extraterrestrial impacts, the effects of which, on living organisms and climatic changes, are still not understood. We carried out a high-resolution investigation on planktonic foraminiferal assemblages in an 8-m-thick segment of the Massignano global stratotype section and point for the Eocene-Oligocene boundary with the aim of assessing the effects that the impacts may have had on the environment and this group of organisms. The studied interval is punctuated by three late Eocene iridium-rich layers, several cosmic signatures, and enhanced levels of ${ }^{3} \mathrm{He}$. The two lower closely spaced iridium anomalies are possibly linked to the Popigai and Chesapeake Bay impact events, respectively, whereas no particular impact event can be assigned to the third anomaly, even if it might be correlated with some large craters. Interpretation of data suggests that all the impacts had no abrupt, dramatic effects on planktonic foraminifera. However, acting as forcing factors, they induced some environmental perturbations and may have contributed to remarkable climate changes superimposed on the general late Eocene cooling trend. The Popigai and Chesapeake Bay impact events triggered significant changes in the water mass structure, in terms of stratification and trophic resources, associated with some climatic excursions that took place within chron $\mathrm{C} 16 \mathrm{n}$.1n and chron $\mathrm{C} 15 \mathrm{r}$ and at the transition between planktonic foraminiferal zones P15 and P16.

The short-term warming pulse recognized after the Popigai impact might have been due to greenhouse effects produced by injection of $\mathrm{CO}_{2}$ into the atmosphere and/or the release of methane hydrate after the impact itself. The dynamic between
\end{abstract}

*cron@info-net.it. 
hydrological and climate changes across the impactoclastic layers as observed at Massignano displays different features at each impact event, probably due to the context in which each occurred in terms of impactor size, location, and target rocks. The relatively long duration of the enhanced cooling following the Chesapeake Bay impact suggests that this event induced a progressive cooling and triggered a feedback mechanism that sustained the initial impact-induced changes. Similar patterns of climatic excursions reported worldwide across the equivalent impact-ejecta horizons indicate that the impact-induced climate changes recorded at Massignano appear to be global in extent.

Keywords: planktonic foraminifera, impacts, hydrological changes, climate changes, late Eocene, Massignano, central Italy.

\section{INTRODUCTION}

The transition from Eocene to Oligocene marks one of the most important steps in Earth's climate history during the Cenozoic, when the "greenhouse" world of the early Eocene changed into the "icehouse" conditions of the early Oligocene (Miller et al., 1991; Zachos et al., 2001, for context). This transition was characterized by global cooling, changes in oceanic circulation, and stepwise faunal and floral turnovers and extinctions, together with a major tectonic reorganization and intensive volcanism (e.g., Boersma and Premoli Silva, 1991; Prothero, 1994; Coxall et al., 2000, 2005; Zachos et al., 2001; Prothero et al., 2003; Wade and Palike, 2004; Tripati et al., 2005; Coxall and Pearson, 2007). The late Eocene (37.2-33.7 Ma) was also marked by a high concentration of impact craters, ejecta layers, and an elevated flux of interplanetary dust particles (e.g., Farley et al., 1998; Montanari and Koeberl, 2000). The two largest craters of the Cenozoic Era, Popigai (northern Siberia), $100 \mathrm{~km}$ in diameter, and Chesapeake Bay (offshore southeastern Virginia), $85 \mathrm{~km}$ in diameter, formed almost simultaneously at ca. $35 \mathrm{Ma}$ and were accompanied by several others essentially isochronous small craters (e.g., Wanapitei and Mistastin, Canada, and Logoisk, Belarus). These craters may have been part of the same event (e.g., Koeberl et al., 1996; Bottomley et al., 1997; Montanari et al., 1998; Poag et al., 2004; Koeberl, 2007). Enhanced levels of ${ }^{3} \mathrm{He}$ clearly indicate that these impacts were related to an $\sim 2.5$-m.y.-long comet or asteroid shower, which produced impact debris (Farley et al., 1998; Tagle and Claeys, 2004; Claeys, 2007; Farley, 2007).

This multiple impact event is recorded in the Massignano section (northeastern Apennines, central Italy), the currently accepted global stratotype section and point (GSSP) for the Eocene-Oligocene boundary (Premoli Silva and Jenkins, 1993). Three Ir-rich layers occur, respectively, at $5.61 \mathrm{~m}$ stratigraphic level from the base (msl), from 6.15 to $6.18 \mathrm{msl}$, with a maximum value at $6.17 \mathrm{msl}$, and from 10.24 to $10.30 \mathrm{msl}$, with a maximum value at $10.28 \mathrm{msl}$ (Montanari et al., 1993; Bodiselitsch et al., 2004), and they are associated with major spikes of extraterrestrial ${ }^{3} \mathrm{He}$ (Farley et al., 1998). The lowest Ir-rich layer contains high concentrations of shocked quartz grains (Clymer et al., 1995, 1996; Langenhorst and Clymer, 1996) and Ni-rich spinel crystals (Pierrard et al., 1998), and it has been interpreted as an impactoclastic horizon dated as old as $35.7 \pm 0.4 \mathrm{Ma}$ (Montanari et al., 1993). According to Bodiselitsch et al. (2004), the Ir anomaly at $5.61 \mathrm{msl}$ is possibly linked to the Popigai impact, dated as old as $35.7 \pm 0.2 \mathrm{Ma}$ (Bottomley et al., 1997), and the Ir anomaly at $6.17 \mathrm{msl}$ might be derived from the Chesapeake Bay impact, which has an inferred age of $35.2 \pm 0.3 \mathrm{Ma}$ to $35.5 \pm 0.3 \mathrm{Ma}$ (Poag et al., 2004). No particular impact event can be assigned to the highest Ir anomaly layer, even if it might be correlated with some large craters (e.g., Wanapitei, Mistastin, and Logoisk). The late Eocene multiple impact event may have played an important role related to the deterioration of the global climate at the end of the Eocene Epoch (Coccioni et al., 2000; Vonhof et al., 2000; Spezzaferri et al., 2002), even if the effects on the climate and on the biosphere are still not understood. The Massignano GSSP, which has well-established integrated stratigraphy and geochronology available for the entire section, provides a unique opportunity to explore whether the late Eocene impact events had any effect on the biosphere and climate with regard to short- and long-term changes. In this study, we focus on the late Eocene 4-12 msl segment of the Massignano section and investigate the response of planktonic foraminiferal assemblages to impact-induced environmental perturbations based on quantitative analyses and statistical treatment of data.

\section{THE MASSIGNANO GSSPAND THE 4-12 MSL SEGMENT}

The Massignano GSSP is exposed at $43^{\circ} 32^{\prime} 13^{\prime \prime} \mathrm{N}, 13^{\circ} 35^{\prime} 36^{\prime \prime} \mathrm{E}$, in an abandoned quarry located along the provincial road of the Conero Regional Natural Park. The section is named after the nearby village of Massignano and is located at $\sim 4 \mathrm{~km}$ northwest of the town of Sirolo, along the Adriatic coast of central Italy (Fig. 1). The marine sedimentary sequence at Massignano section spans the interval from the latest Eocene to the earliest Oligocene and belongs to the Umbria-Marche sedimentary succession, which represents the northwestern sector of the Neotethys Ocean. During the Eocene-Oligocene transition, in this region, the sediments were deposited in an upper to lower bathyal setting at a paleodepth of 1000-1500 m (Coccioni and Galeotti, 2003). 


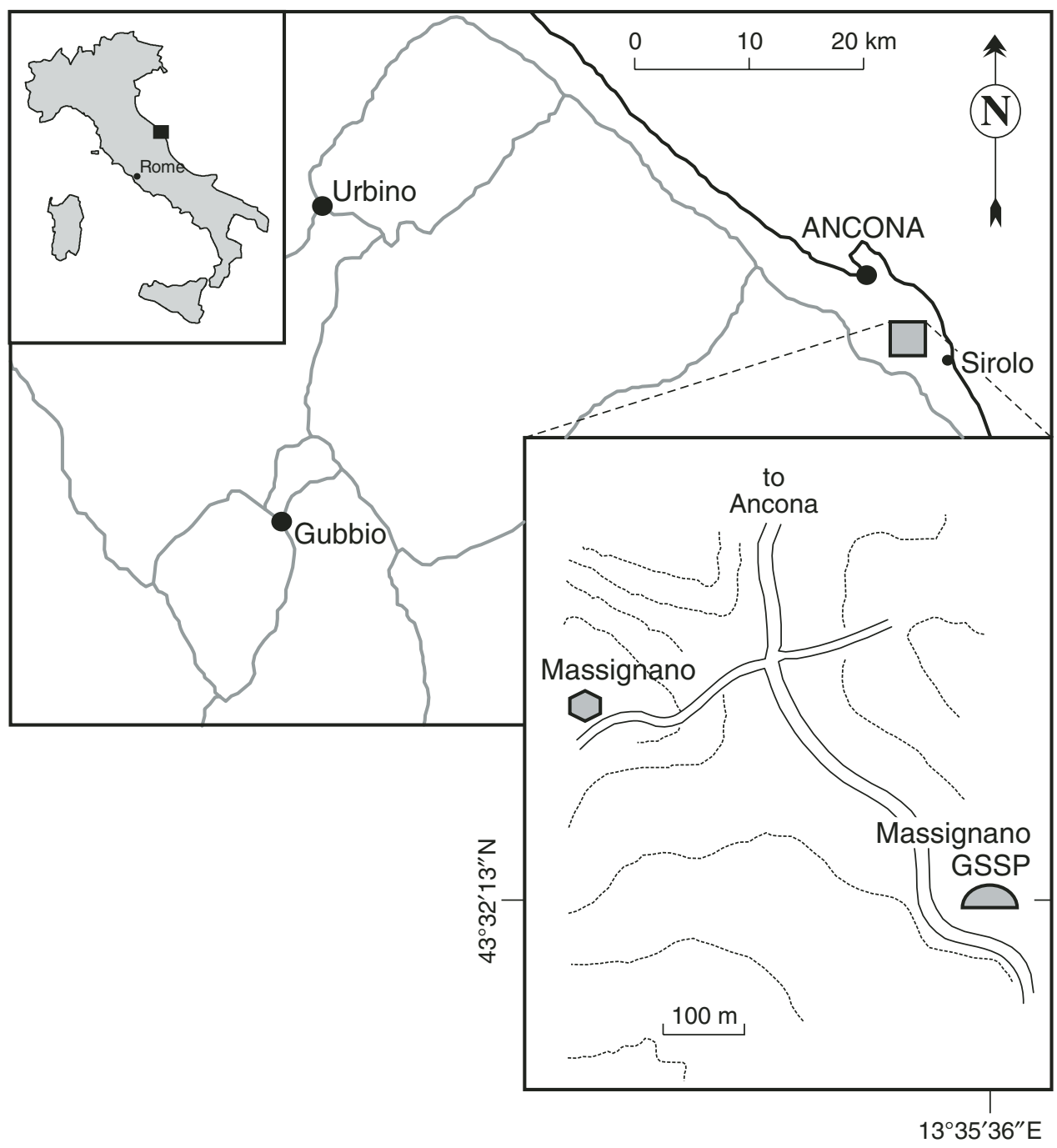

Figure 1. Location map of the Massignano global stratotype section and point (GSSP) for the Eocene-Oligocene boundary.

The exposed continuous and complete sequence is $23 \mathrm{~m}$ thick and consists of reddish and greenish-gray hemipelagic marls, calcareous marls, and marly limestones, rich in well-preserved benthic and planktonic microfossils. The sediments span the upper part of the Scaglia Variegata Formation (12 m thick) and the lower part of the Scaglia Cinerea Formation (11 m thick). In the lower to middle part of the section, they are intercalated with several biotite-rich volcano-sedimentary layers (Coccioni et al., 1988) (Figs. 2 and 3). In particular, the 4-12 msl segment contains five biotite-rich volcaniclastic layers at 5.25, 5.8, 6.5, 7.25, and $7.75 \mathrm{msl}$, respectively (Figs. 2, 4, and 5). Two reddish intervals interrupted by greenish-gray intervals occur in the studied segment. The sediments show evidence of only minor amounts of bioturbation (Coccioni et al., 1988), which appears limited to $\sim 15-20 \mathrm{~cm}$ of vertical dispersion (Coccioni et al., 2000; Huber et al., 2001).

The Massignano GSSP spans the calcareous nannofossil zones NP18 to NP21 of Martini (1971) and CP15a to CP16 of
Okada and Bukry (1980), the planktonic foraminiferal zones P15 to P18 of Blow $(1969,1979)$ and Berggren et al. (1995) and zones E14 to O1 of Berggren and Pearson (2006), the benthic foraminiferal zones BB4 to BB5 of Berggren and Miller (1989), and the dinocyst zones Melitasphaeridium pseudorecurvatum (Mps) to Areosphaeridium diktyoplokus (Adi) of Brinkhuis and Biffi (1993) (Coccioni et al., 1988, 2000; Brinkhuis and Biffi, 1993; Spezzaferri et al., 2002; Monechi et al., 2000) (Fig. 2). The Eocene-Oligocene boundary occurs at $19 \mathrm{msl}$ where the planktonic foraminiferal Hantkenina and Cribrohantkenina, Eocene genera of the Hantkeninidae, both become extinct (Coccioni et al., 1988; Nocchi et al., 1988a; Premoli Silva and Jenkins, 1993).

The Massignano GSSP spans the interval from chron C16n.2n to chron C13n (Bice and Montanari, 1988; Lowrie and Lanci, 1994; Jovane et al., 2004, 2006, 2007, and this volume) (Fig. 2). K-Ar and $\mathrm{Rb}-\mathrm{Sr}$ dating of biotite-rich layers in central Italian magnetostratigraphic sections (Montanari et al., 1988) 
Figure 2. Synoptic stratigraphic scheme of the Massignano global stratotype section and point (GSSP). Lithostratigraphy is after Coccioni et al. (1988) and Jovane et al. (2004, this volume). Biostratigraphy is after Coccioni et al. (1988), Brinkhuis and Biffi (1993), Monechi et al. (2000), Spezzaferri et al. (2002), Coccioni and Galeotti (2003), and Van Mourik and Brinkhuis (2005). Different biozonal schemes are reported according to their authors. Planktonic foraminifera (PF): (1) Blow (1969, 1979), (2) Berggren et al. (1995), and (3) Berggren and Pearson (2006). Benthic foraminifera (BF): Berggren and Miller (1989). Calcareous nannoplankton (CN): (1) Martini (1971) and (2) Okada and Bukry (1980). Dinoflagellate cysts (DC): Brinkhuis and Biffi (1993). Signatures are after Coccioni et al. (1988), Montanari et al. (1988, 1993), Clymer et al. (1995, 1996), Langenhorst and Clymer (1996), Pierrard et al. (1998), and Jovane et al. (2004). Iridium profile is after Montanari et al. (1993) and Bodiselitsch et al. (2004). Magnetostratigraphy is after (1) Bice and Montanari (1988), (2) Lowrie and Lanci (1994), and (3) Jovane et al. (2004, 2007, this volume).

\begin{tabular}{|c|c|c|c|c|c|c|c|c|c|c|c|c|c|c|c|c|c|c|}
\hline \multirow{3}{*}{$\begin{array}{l}\text { 등 } \\
\text { 분 }\end{array}$} & \multirow{3}{*}{ 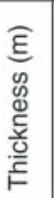 } & \multirow{3}{*}{ 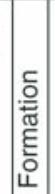 } & \multirow{3}{*}{$\begin{array}{l}\text { 즘 } \\
\text { 응 } \\
\text { 돓 }\end{array}$} & \multirow{3}{*}{ 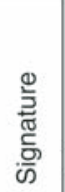 } & \multirow[b]{3}{*}{ 흥 } & \multicolumn{7}{|c|}{ BIOSTRATIGRAPHY } & \multicolumn{2}{|c|}{ Ir (ppt) } & \multicolumn{4}{|c|}{\begin{tabular}{|c|} 
MAGNETO- \\
STRATIGRAPHY \\
\end{tabular}} \\
\hline & & & & & & & $\begin{array}{l}\text { PF } \\
\text { ONE }\end{array}$ & & 只 & & & 邑 & & & & (1) & (2) & (3) \\
\hline & & & & & & (1) & (2) & (3) & แ & (1) & (2) & Oํ. & $\stackrel{\circ}{\square}$ & ః્ণ & ర్లి & (II) & (द) & (उ) \\
\hline
\end{tabular}

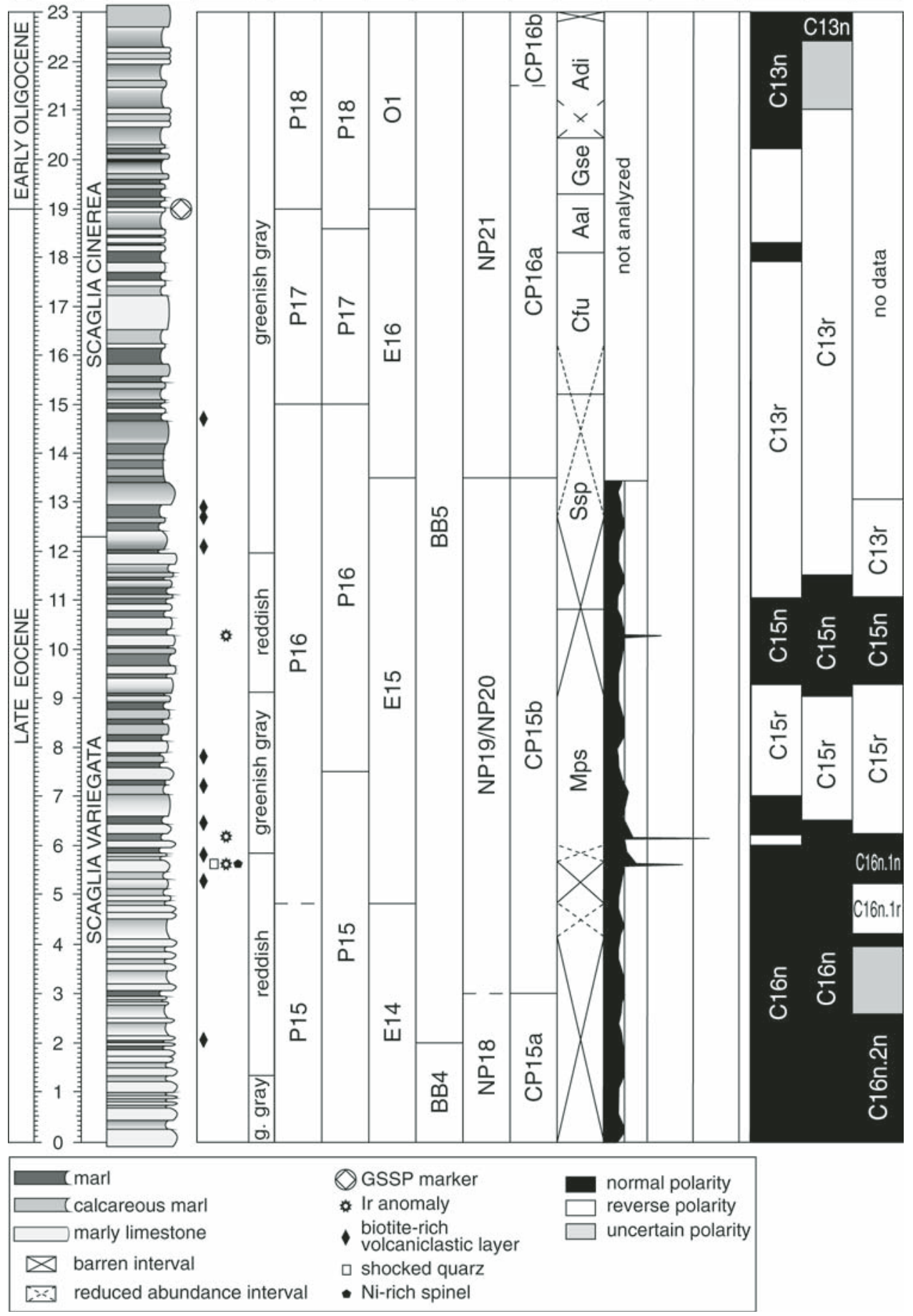




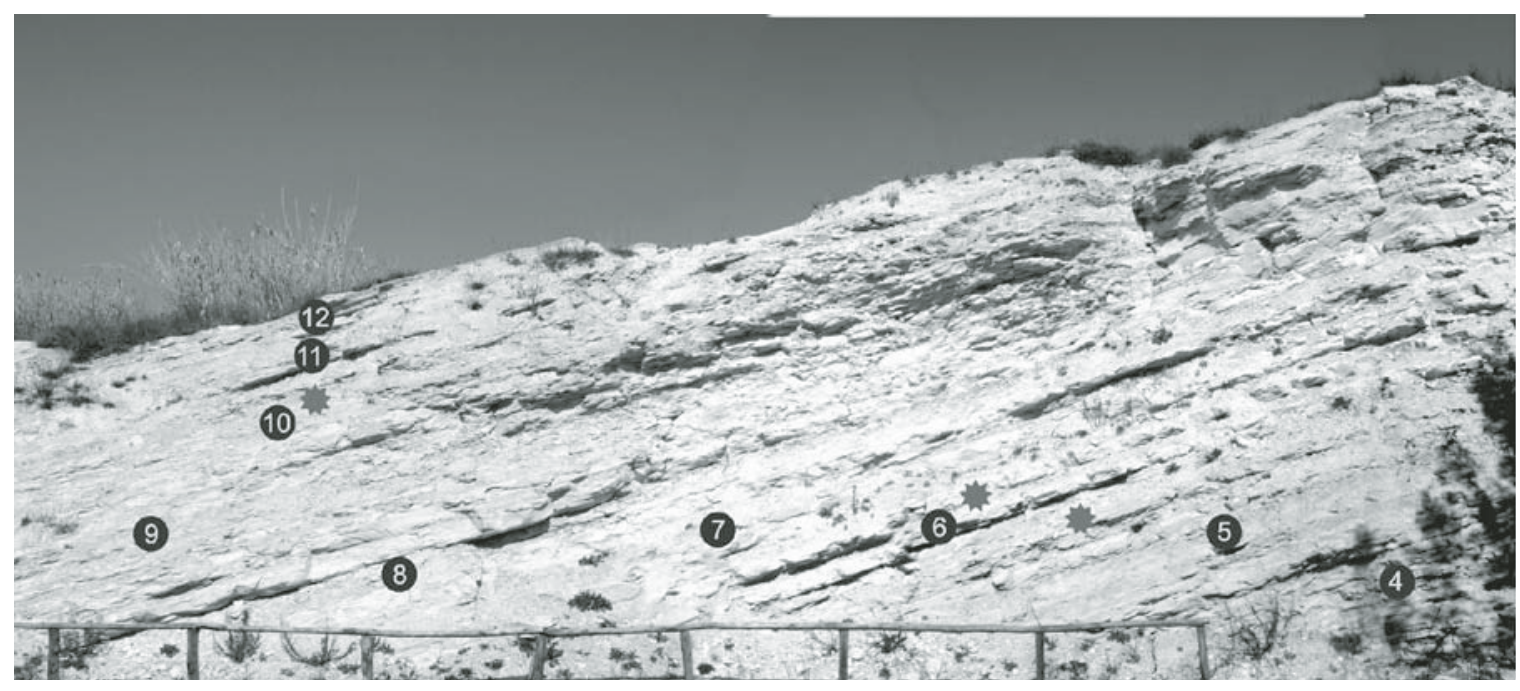

Figure 3. Outcrop photo of the 4-12 m stratigraphic level from the base (msl) segment at Massignano. Numbers correspond to the meters of the measured section. Asterisks mark locations of the impactoclastic layers at 5.61, 6.17, and $10.28 \mathrm{msl}$.

gave an estimated age of $33.7 \pm 0.5 \mathrm{Ma}$ for the Eocene-Oligocene boundary, which has been incorporated as a calibration point in the latest polarity time scales (Cande and Kent, 1992, 1995; Berggren et al., 1995). Additional results from ${ }^{40} \mathrm{Ar} /{ }^{39} \mathrm{Ar}$ dating of biotites (Odin et al., 1991) and U/Pb dating of zircons and monazites (Oberli and Meier, 1991) were combined with the earlier data to yield revised mean ages of $35.4 \pm 0.3 \mathrm{Ma}, 34.5 \pm 0.3 \mathrm{Ma}$, and $34.2 \pm 0.2 \mathrm{Ma}$ for the biotite horizons at 7.25, 12.9, and $14.7 \mathrm{msl}$, respectively. A new magnetostratigraphic data set, combined with the results of the astronomical tuning of the Massignano section (Jovane et al., 2006), allowed researchers to refine the dates for the bio- and chronostratigraphic events previously recorded throughout the succession and to place the EoceneOligocene boundary at $33.7 \mathrm{Ma}, 0.2 \mathrm{~m}$.y. younger than in the time scale of Gradstein et al. (2004) (Jovane et al., 2007). Based on the magnetostratigraphy provided by Jovane et al. (2007) and the numerical ages from Cande and Kent (1995), the mean sedimentation rate of the 4-12 msl segment at Massignano is $0.73 \mathrm{~cm} / \mathrm{k}$.y. Accordingly, this segment would span $~ 1.1$ m.y. (Figs. 4 and 5).

\section{MATERIALS AND METHODS}

High-resolution sampling of the 4-12 msl segment at Massignano GSSP was conducted at intervals of 5-10 cm, collecting a total of 87 samples. Samples were prepared using standard techniques for preparation of washed residues from marls, calcareous marls, and marly limestones. Samples were disaggregated with hydrogen peroxide and rinsed through a $40 \mu \mathrm{m}$ sieve. The washed residues were additionally soaked in Desogen for several hours and then immersed in an ultrasonic bath for a few minutes. The final washed residues were dry-sieved into three different size fractions: $40-150 \mu \mathrm{m}, 150-250 \mu \mathrm{m}$, and $>250 \mu \mathrm{m}$. The residues were studied with a binocular microscope for their planktonic foraminiferal content. The $40 \mu \mathrm{m}$ mesh sieve was used to retain very small species, such as small acarininids, chiloguembelinids, tenuitellids, and pseudohastigerinids, which have important paleoceanographic implications (e.g., Premoli Silva and Boersma, 1988; Spezzaferri, 1995; Pearson et al., 2006).

Quantitative analyses of planktonic foraminiferal assemblages were performed on the same samples previously used for biostratigraphy, following the standard method of Haq et al. (1977), and applied by Premoli Silva and Boersma (1989), Spezzaferri and Premoli Silva (1991), and Spezzaferri (1995). Generic and specific concepts adopted here are those of Premoli Silva and Boersma (1989), Spezzaferri (1994), and Pearson et al. (2006). Planktonic foraminiferal species were then assembled, whenever possible, in groups displaying phylogenetic affinities and environmental significance as reported in Premoli Silva and Boersma (1988) and Spezzaferri (1995). Grouping was necessary because the scarcity of specimens of some species sometimes prevented a correct paleoclimatic interpretation. Species and group abundances were then transformed to percentages of the total planktonic foraminiferal fauna, and percentage curves were constructed. Abundance data of planktonic foraminifers were double-squareroot transformed (no standardization, no further species reduction) in order to limit the contribution of the most abundant, ubiquitous species with respect to the less abundant species and to simplify the interpretation of the data structure (Field et al., 1982).

Multivariate statistical analysis was performed with the software PAST version 1.67. The data were used in hierarchical agglomerative clustering based on Bray-Curtis similarity (Clifford and Stephenson, 1975). On the basis of the same similarity matrix, samples were ordered by nMDS (non-metric multidimensional scaling; Kruskal, 1977). The nMDS plot has no dimensions and no axes and can be arbitrarily scaled, located, rotated, or inverted; it gives the relationship of samples relative to each other. 


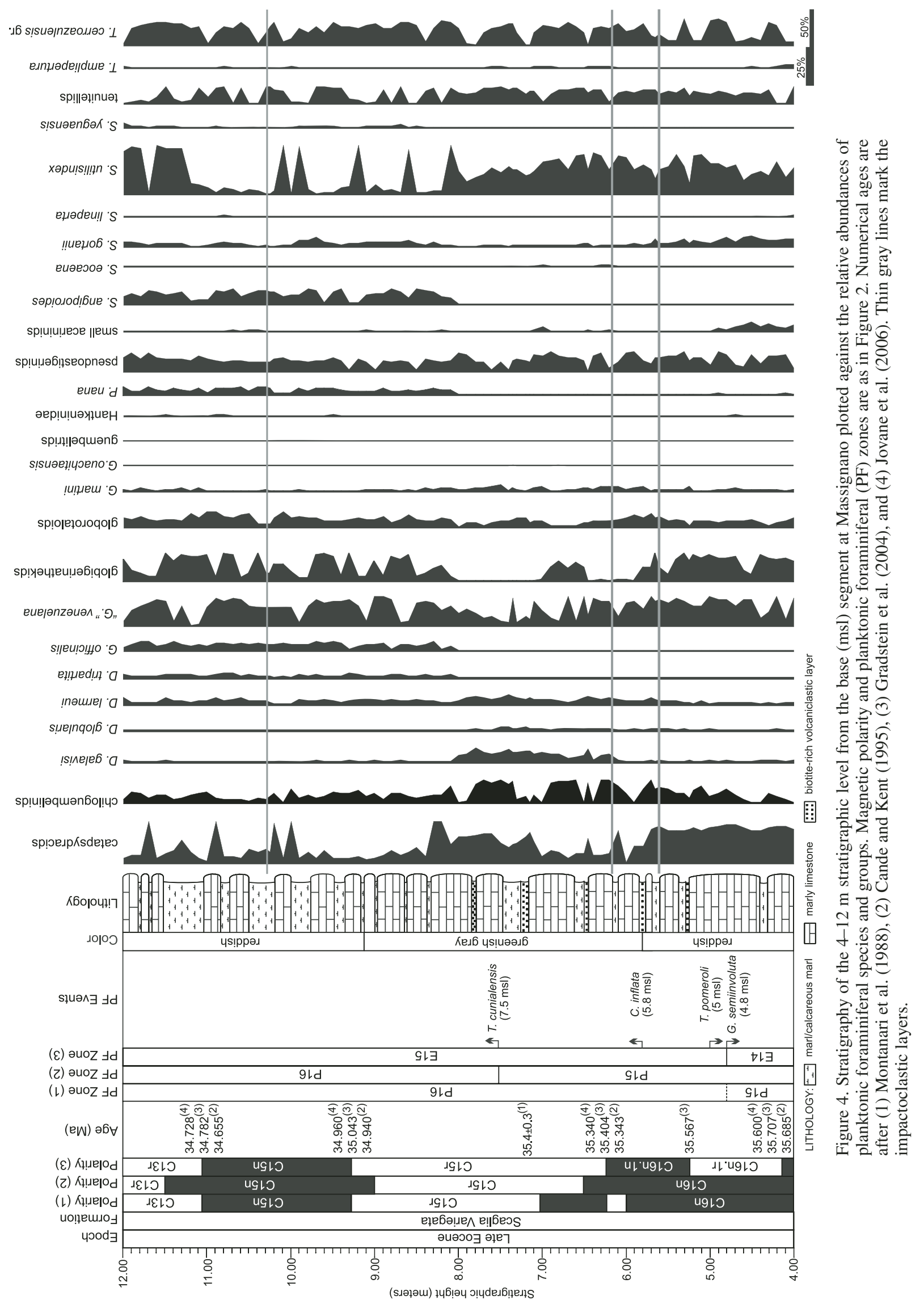




\begin{tabular}{|c|c|c|c|c|c|c|c|c|c|c|}
\hline \multirow{3}{*}{ 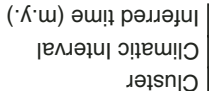 } & - & 영 & ֻ & 垈 & : & 岂 & to & कृ & त̂́ & 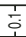 \\
\hline & \multicolumn{5}{|c|}{$\Xi$} & \multicolumn{3}{|c|}{$\exists$} & \multicolumn{2}{|c|}{ - } \\
\hline & \multicolumn{5}{|c|}{0} & & & & \multicolumn{2}{|c|}{$\varangle$} \\
\hline
\end{tabular}

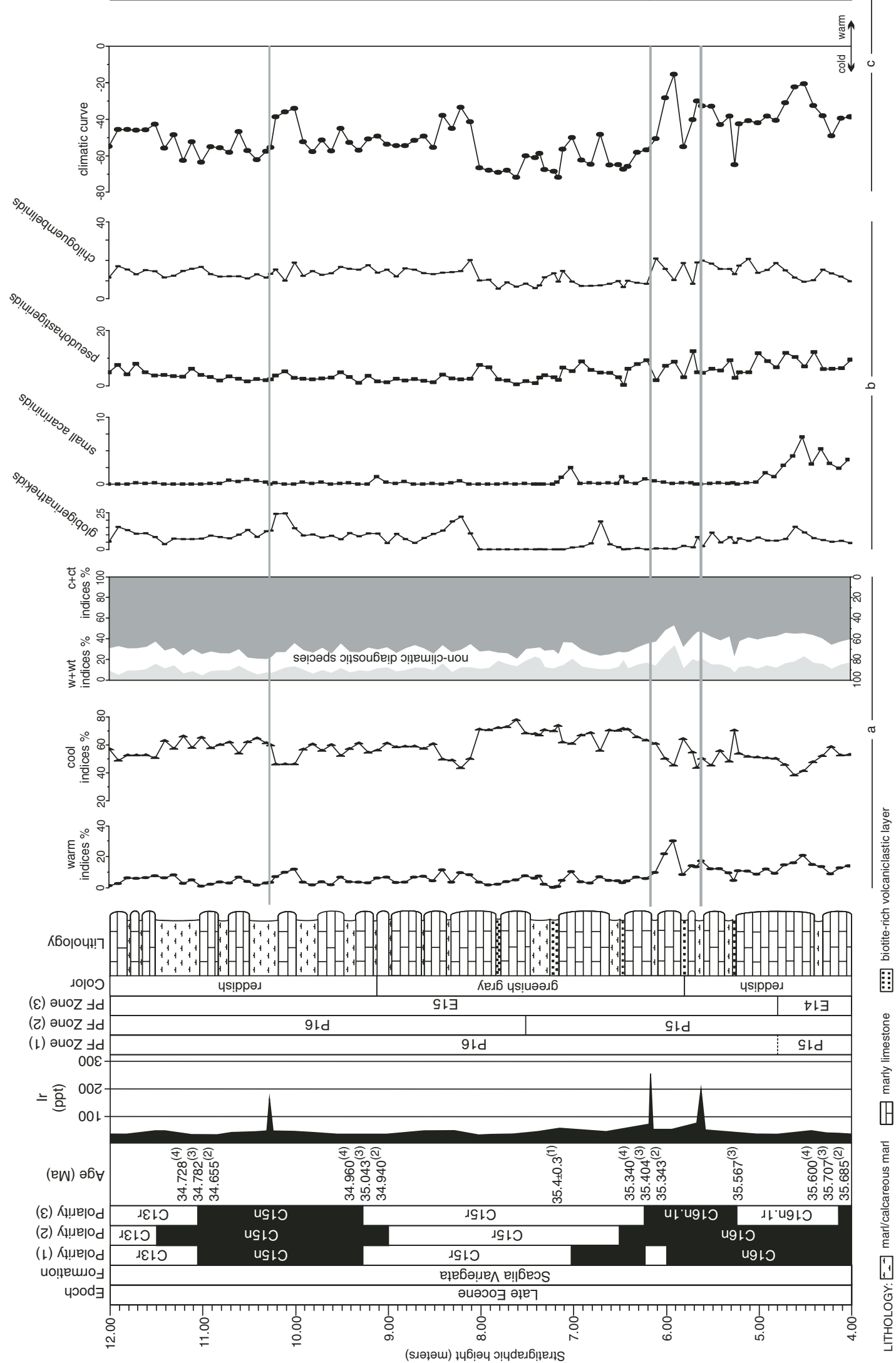

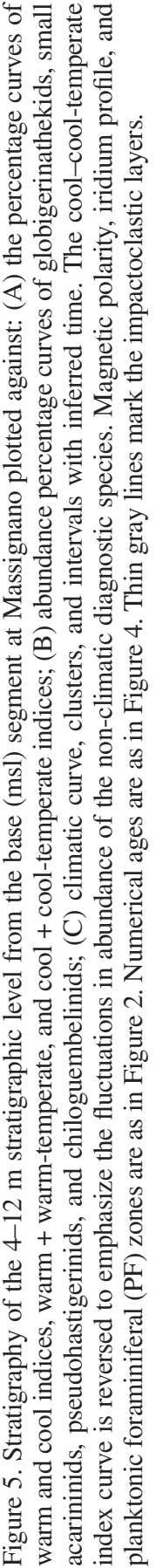




\section{RESULTS}

\section{Planktonic Foraminiferal Assemblages and Biostratigraphy}

Planktonic foraminiferal assemblages are relatively well preserved, rich, and well diversified throughout the 4-12 msl segment (Fig. 4; Table 1). Specimens often display a slight calcitic overgrowth or infilling, which prevented reliable oxygen and carbon isotopes analyses; consequently, our observations are only based on assemblages.

The 4-12 msl segment is dominated by catapsydracids (Catapsydrax dissimilis, C. unicavus), chiloguembelinids, "Globigerina" venezuelana, globigerinathekids (Globigerinateka index, G. luterbacheri, G. semiinvoluta, G. subconglobata, G. tropicalis), globorotaloids (Globorotaloides euvariabilis, Globorotaloides sp. 1), pseudohastigerinids, Subbotina utilizindex, tenuitellids, and Turborotalia cerroazulensis group (T. cerroazulensis, T. cocoaensis, T. cunialensis, T. pomeroli), which occur throughout (Fig. 4; Table 1). Globoturborotalita ouachitaensis, Hantkeninidae (Cribrohantkenina inflata, Hantkenina alabamensis), Subbotina eocaena, S. linaperta, S. yeguaensis, Turborotalia ampliapertura, and guembelitrids occur discontinuously and in very low numbers. Subbotina utilizindex and T. ampliapertura, which according to Pearson et al. (2006) have their first occurrence (FO) in zone E15, are already present within the uppermost part of zone E14. Dentoglobigerina tripartita, Globigerina officinalis, Paragloborotalia nana, and Subbotina angiporoides are continuously present only from the upper half of the studied segment.

The bioevents identified in the studied segment are (from bottom to top): (1) last occurrence (LO) of Globigerinatheka semiinvoluta (4.8 msl), (2) LO of Turborotalia pomeroli (5 msl), (3) FO of Cribrohantkenina inflata $(5.8 \mathrm{msl})$, and (4) FO of Turborotalia cunialensis (7.5 msl) (Coccioni et al., 1988, 2000; Spezzaferri et al., 2002) (Fig. 4).

The 4-12 msl segment spans the uppermost part of zone P15 to the upper part of zone P16 of Blow (1969, 1979), the upper part of zone P15 to the middle part of zone P16 of Berggren et al. (1995), and the uppermost part of zone E14 to the lowermost part of zone O1 of Berggren and Pearson (2006) (Figs. 2, 4, and 5).

\section{Paleoenvironmental Remarks}

The paleoclimatic significance and the paleoecology of Eocene planktonic foraminifera are generally deduced from their latitudinal abundance patterns, stable isotopic paleobiology, and from comparison of these parameters to those of modern counterparts.

The paleoecology (preferred biogeographical distribution and life position in the water column) and the paleoclimatic significance of the recognized species and groups are based on the abundant literature, largely following Douglas and Savin (1978), Boersma et al. (1979, 1987), Keller (1983), Poore and Matthews (1984), Nocchi et al. (1988b), Premoli Silva and Boersma (1988,
1989), Stott et al. (1990), Barrera and Huber (1991, 1993), Boersma and Premoli Silva (1991), Spezzaferri and Premoli Silva (1991), Pearson et al. (1993, 1997, 2001, 2006), Spezzaferri (1995), Van Eijden and Ganssen (1995), Pearson and Palmer (1999), Coxall et al. (2000), and Wade and Kroon (2002).

According to the aforementioned literature, we consider the following to be warm-water indices: the small acarininids, Globoturborotalita martini, Hantkeninidae, and the T. cerroazulensis group. As cool-water indices, we consider catapsydracids, Globigerina officinalis, globorotaloids, low-spired subbotininds (S. angiporoides, S. eocaena, S. linaperta, S. utilizindex), "Globigerina" vеnеzuelana, and tenuitellids. We regard globigerinathekids, $P$. nana, and T. ampliapertura as cool temperate-water indices, and as warm-temperate water indices, we consider Dentoglobigerina galavisi, D. larmeui, and D. tripartita. Preferred geographic distribution and habitat and paleoclimatic significance of planktonic foraminiferal species and groups identified at Massignano are summarized in Table 2, and Figure 5 shows the abundance curves of the paleoclimatic indicators listed here.

The curve of the warm-water indices shows values ranging from $0.7 \%$ to $30.1 \%$, decreasing upward. Positive peaks of $20.9 \%, 30.1 \%$, and $12.1 \%$ occur at $4.5,5.9$, and $10 \mathrm{msl}$, respectively. The curve of the cool-water indices can be subdivided into three intervals: the first one from 4 to $6.1 \mathrm{msl}$, with average values around $52 \%$ and positive peaks of $70 \%$ and $64 \%$, respectively, at 5.25 and $5.8 \mathrm{msl}$; the second one from 6.2 to $8 \mathrm{msl}$, with average values around $68 \%$; the third one from $8 \mathrm{msl}$ to the top of the studied segment, with average values around 56\% (Fig. 5). The abundance curves of the warm and warm-temperate indices and of the cool and cool-temperate indices show a pattern similar to that obtained for the warm- and cool-water indices (Fig. 5). The abundance curve of the globigerinathekids shows higher numbers in the upper half of the studied segment, with average values increasing from $4 \%$ to $11 \%$. Values range from $0 \%$ to $\sim 25 \%$ at $10.1 \mathrm{msl}$ (Fig. 5). The curve of the small acarininids shows values ranging up to $7.1 \%$. Relatively higher abundances are observed from the bottom of the studied segment up to $4.9 \mathrm{msl}$, with a peak at $4.5 \mathrm{msl}$. From here upward, the small acarininids are absent or occur with very low numbers (Fig. 5). The curves of pseudohastigerinids and chiloguembelinids show marked fluctuations from the bottom of the studied segment up to $6.2 \mathrm{msl}$ and an evidently opposite trend in the interval between the impactoclastic layers related to the Popigai and Chesapeake Bay impact events (Fig. 5).

\section{Climatic Curve}

The climatic curve is derived from the algebraic sum of percent abundance of warm (positive) and cool (negative) indices as proposed by Cita et al. (1977) and applied by Spezzaferri and Premoli Silva (1991) and Spezzaferri (1995). In the biotite-rich volcaniclastic layers, only minor abundances of warm-water indices are observed (Fig. 5). Therefore, we consider the planktonic foraminifera-based curve to be reliable. 
The climatic curve throughout the 4-12 msl segment allows us to recognize three discrete climatic intervals (CI-I to CI-III, from bottom to top) separated by two major shifts: the relatively warmest CI-I interval extends from 4 to $6.1 \mathrm{msl}$, with an average value of $-38.1 \%$, and shows two significant warmer pulses in the intervals from 4.4 to $4.7 \mathrm{msl}$ and from 5.8 to $6 \mathrm{msl}$ and two major cooler pulses at 5.25 and $5.8 \mathrm{msl}$; the relatively cooler CI-II extends from 6.2 to $8 \mathrm{msl}$, with an average value of $-63.4 \%$; the relatively warmer CI-III extends from $8.1 \mathrm{msl}$ up to the top of the studied segment, with an average value of $-50.6 \%$, and shows two significant warmer pulses in the intervals from 8.1 to $8.4 \mathrm{msl}$ and from 10 to $10.2 \mathrm{msl}$ (Fig. 5).

The first two closely spaced impact events fall within the CI-I, and the last impact lies within the CI-III interval. Approximately 5.5 k.y. after the first impact (Popigai), some warmer conditions than those directly below the impact itself are recorded by the sample at $5.65 \mathrm{msl}$. Subsequently, climatic episodes alternate between, from bottom to top: (1) a cooling episode, up to $5.8 \mathrm{msl}$, therefore lasting for 20 k.y., (2) a marked warming pulse, lasting for 27 k.y., between 5.8 and 6 msl, and (3) a further cooling episode, lasting for $23 \mathrm{k} . \mathrm{y}$. from $6.0 \mathrm{msl}$ up to the second impact (Chesapeake Bay). The relatively cooler CI-II interval that followed the Chesapeake Bay impact lasted for 247 k.y. The last impact falls within a cooling episode occurring from 10 to $10.4 \mathrm{msl}$ and lasting for $\sim 55 \mathrm{k} . \mathrm{y}$. About $\sim 16 \mathrm{k}$.y. after this impact, a subsequent return to less cool conditions occurs that extends up to the top of the studied segment (Fig. 5).

\section{Statistical Treatment of Data}

Since patterns of community structures are often not readily apparent (Clarke and Warwick, 1994), we conducted statistical analyses of our data to better identify and characterize changes in planktonic foraminiferal assemblages, and to relate them to changing environmental conditions following the impact events.

At the $84 \%$ level of Bray-Curtis similarity, three clusters (A, B, and C in Figs. 6 and 7) were recognized. At the same level of dissimilarity, the differences among clusters were identified by the average abundance of species and/or groups. Cluster A differs from cluster B by higher percentages of chiloguembelinids, globigerinathekids, small acarininids, Subbotina gortanii, pseudohastigerinids and T. cerroazulensis group and lower percentages of catapsydracids, D. galavisi, and Dentoglobigerina larmeui. Cluster $\mathrm{B}$ differs from cluster $\mathrm{C}$ by higher percentages of catapsydracids, D. galavisi, D. larmeui, "G." venezuelana, S. utilizindex, and lower percentages of chiloguembelinids, G. officinalis, globigerinathekids, $P$. nana, $S$. angiporoides, tenuitellids, and T. cerroazulensis group. Cluster $\mathrm{C}$ differs from cluster A by higher percentages of catapsydracids, globigerinathekids, globorotaloids, tenuitellids, $S$. angiporoides, and $P$. nana, and lower percentages of small acarininids, $S$. utilizindex, and $T$. cerroazulensis group.

The planktonic foraminiferal assemblages of cluster $\mathrm{C}$ can be considered relatively cooler than those of cluster A but relatively warmer than those of cluster B (Figs. 6 and 7). In fact, cluster A shows the lowest abundance of cool species and concurrently the highest abundance of warm species, such as small acarininids and T. cerroazulensis group. Moreover, cluster B has the highest abundances of catapsydracids, "G." venezuelana, and S. utilizindex and the lowest abundance of $T$. cerroazulensis group and can be considered to be the coolest cluster of the studied segment.

The clusters recognized through the statistical treatment of our data fit well with the climatic intervals documented by means of the climatic curve (Figs. 5, 6 , and 7). Remarkably, the line IMPACT 1, which corresponds to the Ir anomaly at $5.61 \mathrm{msl}$ (Popigai impact), allows us to subdivide cluster A into subclusters A1 (pre-impact 1) and A2 (postimpact 1 to pre-impact 2), with only one exception, the sample found at $5.65 \mathrm{msl}$ (Fig. 7). Subcluster A2 differs from subcluster A1 by lower abundances of catapsydracids, globigerinathekids, and small acarininids, and higher abundances of D. larmeui, globorotaloids, and T. cerroazulensis group. The most significant feature recognized through the multivariate statistical analysis in the nMDS plot is the line IMPACT 2, which corresponds to the Ir anomaly at $6.17 \mathrm{msl}$ (Chesapeake Bay impact) (Fig. 7). This line clearly separates cluster A from cluster B, which correspond to CI-I and CI-II, respectively. The multivariate statistical analysis shows that significant changes in planktonic foraminiferal assemblages did not take place across the stratigraphical interval, including the Ir anomaly at $10.28 \mathrm{msl}$ (line IMPACT 3) (Fig. 7).

\section{DISCUSSION}

\section{High-Resolution Impact Stratigraphy, Geochronology, and Magnetochronology at Massignano: Implications for Global Correlation}

On the basis of the available data from the Massignano GSSP, we provide here an updated magnetobiostratigraphic, geochronologic, and magnetochronologic constraint for the late Eocene impactoclastic layers at Massignano that will be useful for global correlation of equivalent horizons.

In terms of biostratigraphy, both the Ir anomalies at 5.61 and $6.17 \mathrm{msl}$, linked respectively to the Popigai and Chesapeake Bay impact events, fall in the uppermost part of planktonic foraminiferal zone P15 of Berggren et al. (1995), which is in the lowermost part of E15 of Berggren and Pearson (2006) and in the middle part of calcareous nannofossil zone NP19/20 of Martini (1971) (Figs. 2, 4, and 5). The Ir anomaly at $10.28 \mathrm{msl}$ lies in the middle part of planktonic foraminiferal zone P16 of Berggren et al. (1995), which is the upper part of zone E15 of Berggren and Pearson (2006) and calcareous nannofossil zone NP19/20 of Martini (1971) (Figs. 2, 4, and 5).

As for magnetostratigraphy, different data are available. Following Bice and Montanari (1988) and Lowrie and Lanci (1994), the Popigai and Chesapeake Bay impacts fall within the uppermost part of chron C16n, whereas following Jovane et al. (2007), they are more precisely constrained within the upper half of chron C16n.1n. The last impact consistently lies within chron C15n (Figs. 2, 4, and 5). 


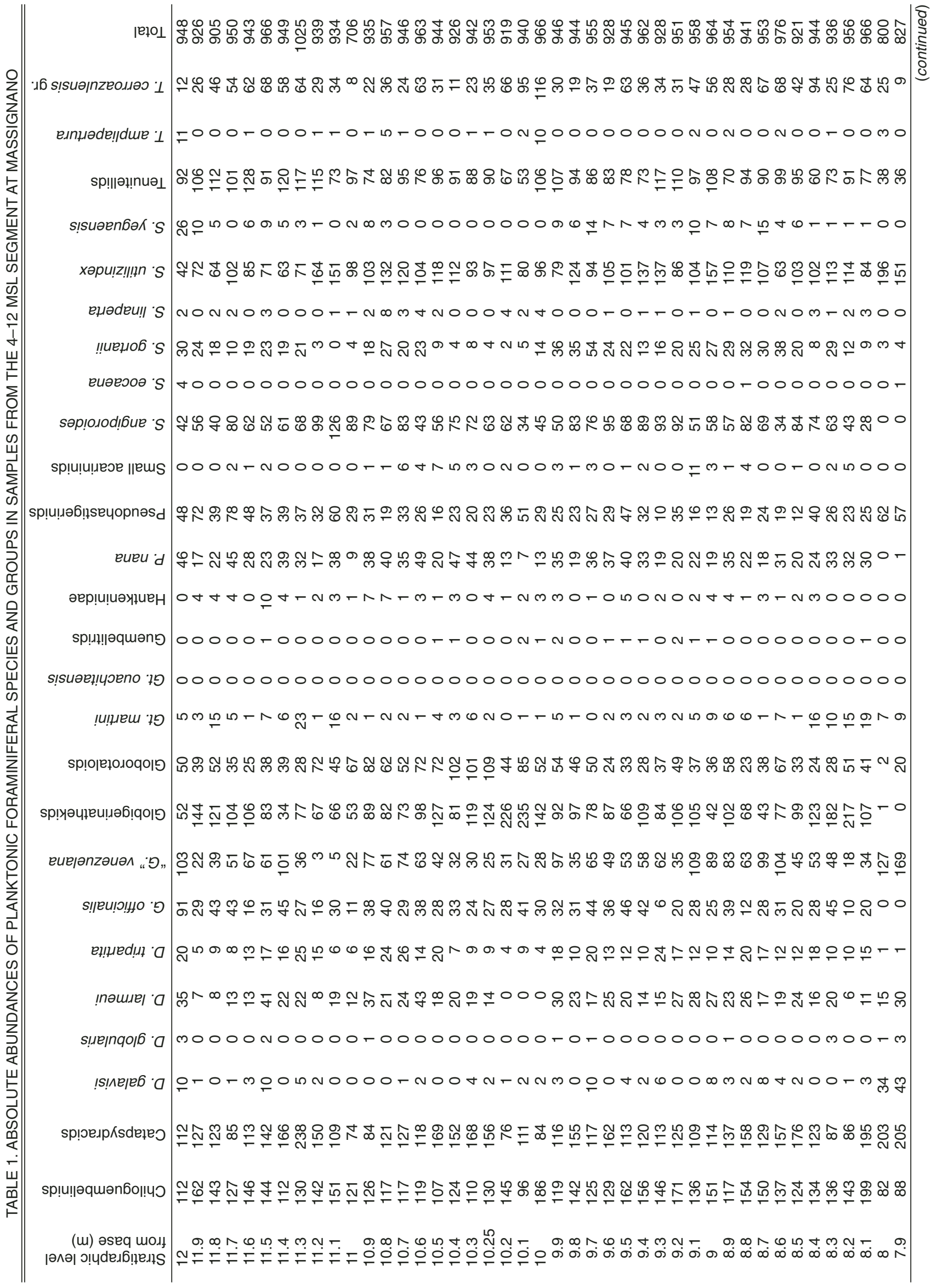




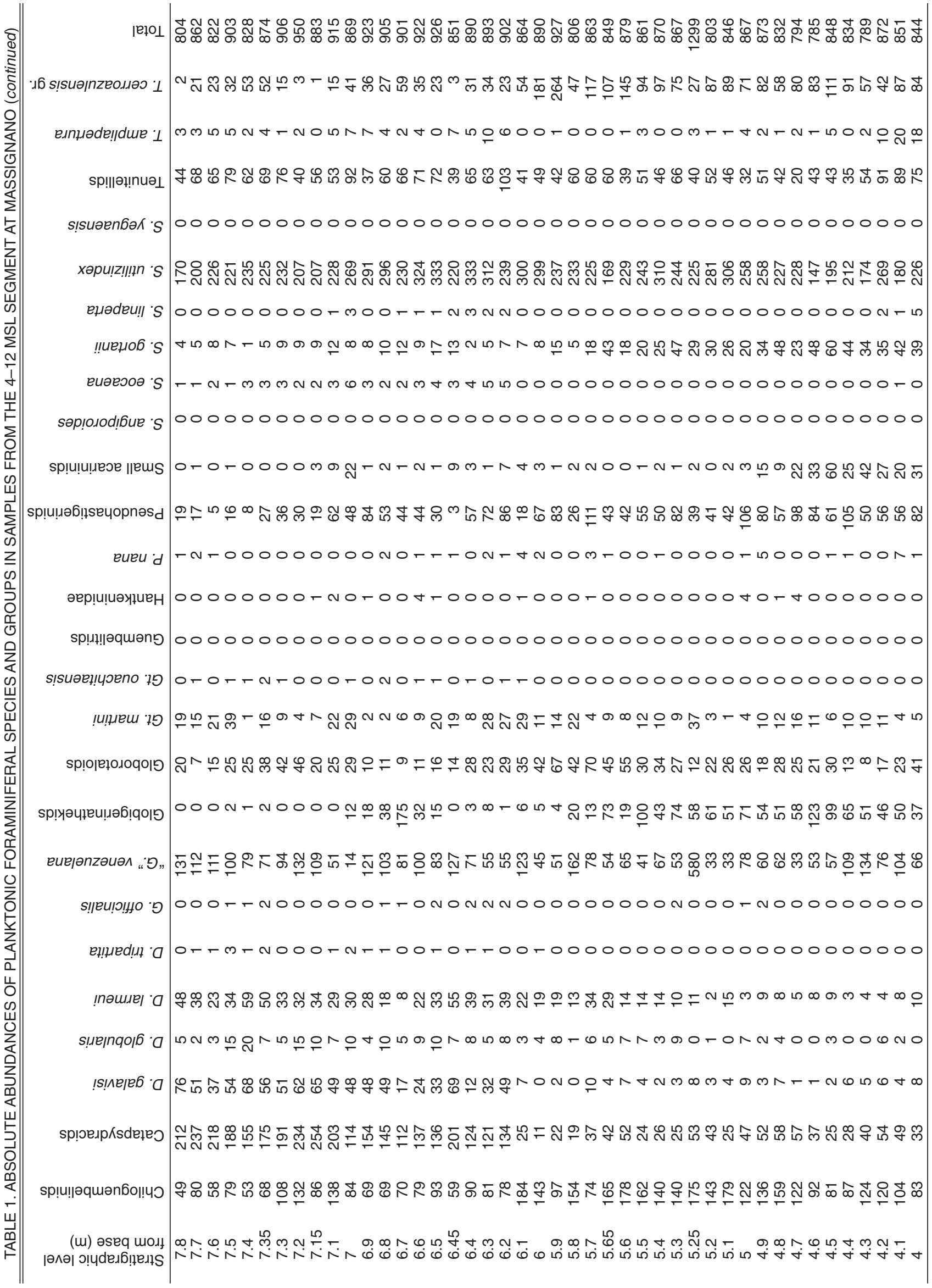




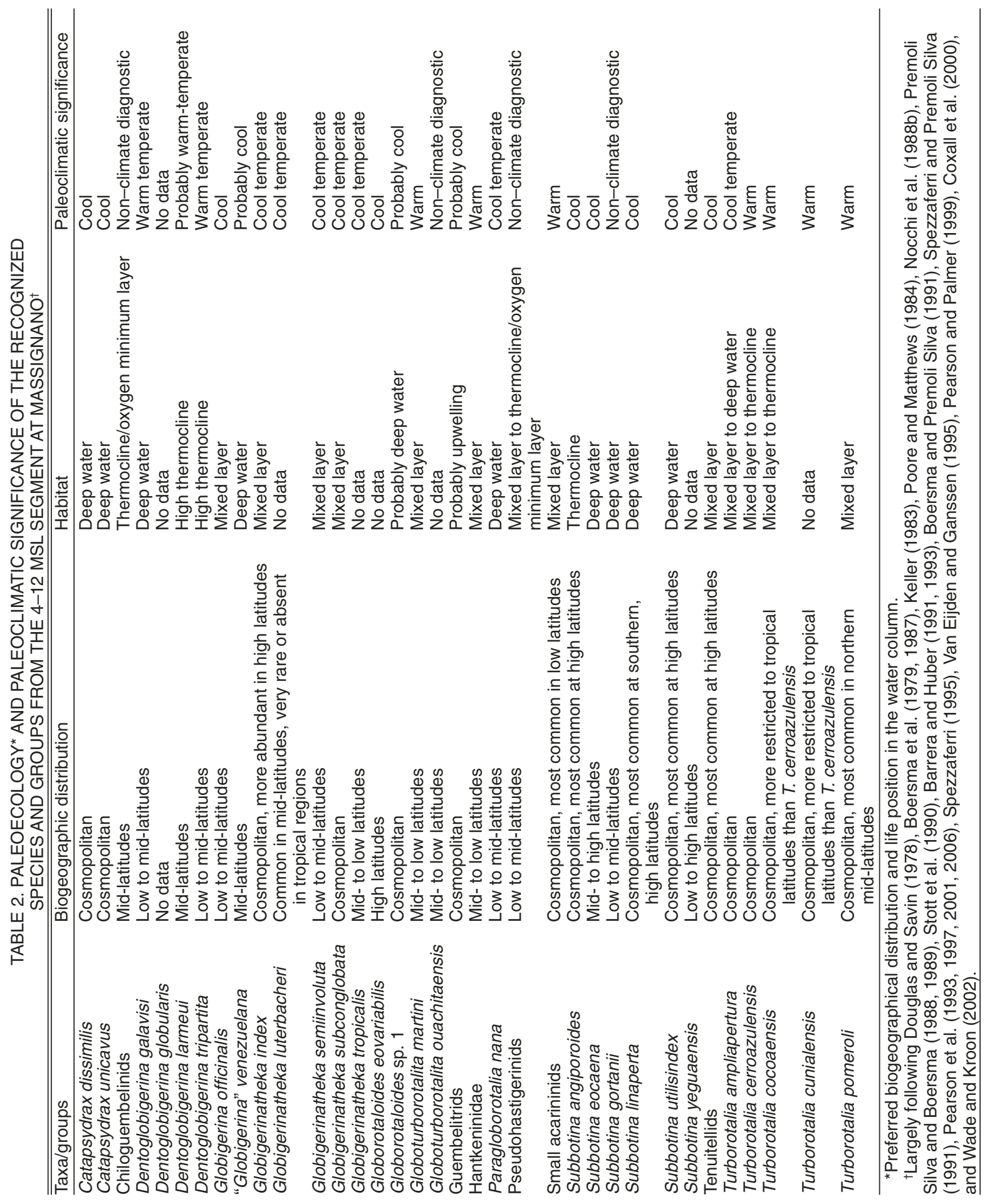




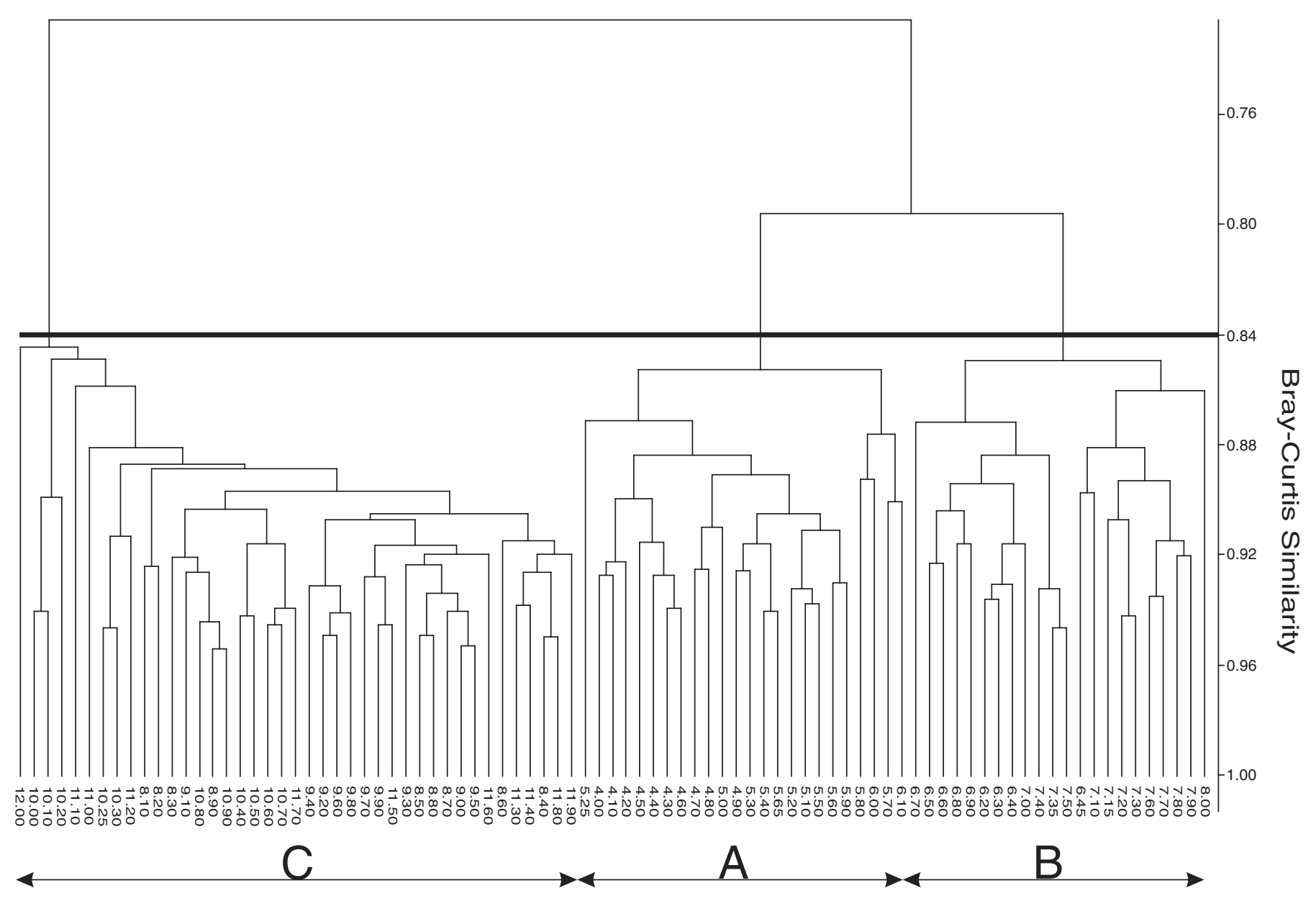

Figure 6. Classification of samples of the 4-12 m stratigraphic level from the base (msl) segment at Massignano using hierarchical agglomerative cluster analysis based on the Bray-Curtis similarity matrix. Three clusters (A, B, and C) were identified at the $84 \%$ level of Bray-Curtis similarity.

In terms of geochronology, an interpolated age of $35.7 \pm$ $0.4 \mathrm{Ma}$ for the impactoclastic layer at $5.61 \mathrm{msl}$ was derived from radioisotopic dating performed in the volcaniclastic layers at Massignano (Montanari et al., 1993) (Figs. 4 and 5). On the basis of the magnetochronologic ages provided by Cande and Kent (1995), Gradstein et al. (2004), and Jovane et al. (2006) for chrons C16n.2r, C16.1n, and C15n (Figs. 4 and 5), the numerical ages for the Popigai, the Chesapeake Bay, and the unidentified impact events at Massignano would be 35.417-35.493 Ma, 35.346-35.411 Ma, and 34.778-34.894 Ma, respectively. On the basis of the mean sedimentation rate of $0.73 \mathrm{~cm} / \mathrm{k} . \mathrm{y}$. (Jovane et al., 2007) and of the magnetochronologic ages, the time interval between the Popigai and Chesapeake Bay impacts would span $\sim 77$ k.y. on average.

A comparison of the high-resolution magnetobiostratigraphic and geochronologic data from the Massignano GSSP with those from Ocean Drilling Program (ODP) Holes 689B (Maud Rise, Southern Ocean) and 1090B (South Atlantic sector of the Southern Ocean), and the Chickahominy Formation in the Kiptopeke core hole (offshore southeastern Virginia) pro- vides a valuable time constraint and global correlation for the late Eocene impact-ejecta horizons.

At ODP Hole 689B, the Antarctic impact-ejecta horizon that is interpreted to represent the clinopyroxene-bearing spherule-strewn field of the North America tektite strewn field, providing an ${ }^{40} \mathrm{Ar} /{ }^{39} \mathrm{Ar}$ date of $35.5 \mathrm{Ma}$ (Glass et al., 1982; Vonhof et al., 2000), lies within chron C16n.1n (Florindo and Roberts, 2005). This horizon falls in the uppermost part of planktonic foraminiferal Globorotaloides suteri (AP12) zone (Stott and Kennett, 1990), which would correspond to the uppermost part of zone P15 of Berggren et al. (1995) and to the calcareous nannofossil NP19/20 equivalent zone (Wei and Wise, 1992; see also Berggren et al., 1995).

According to Pusz et al. (this volume), no distinct stratigraphic separation is found between the microtektite and microkrystite layers at Site 1090, recognized as its own layer (Liu et al., 2000; Kyte and Liu, 2002). Following the magnetostratigraphic age control provided by Channell et al. (2003), the Ir anomaly located $10 \mathrm{~cm}$ above the two stratigraphically coeval, but geochemically distinct, Chesapeake Bay impact structure microtektite 


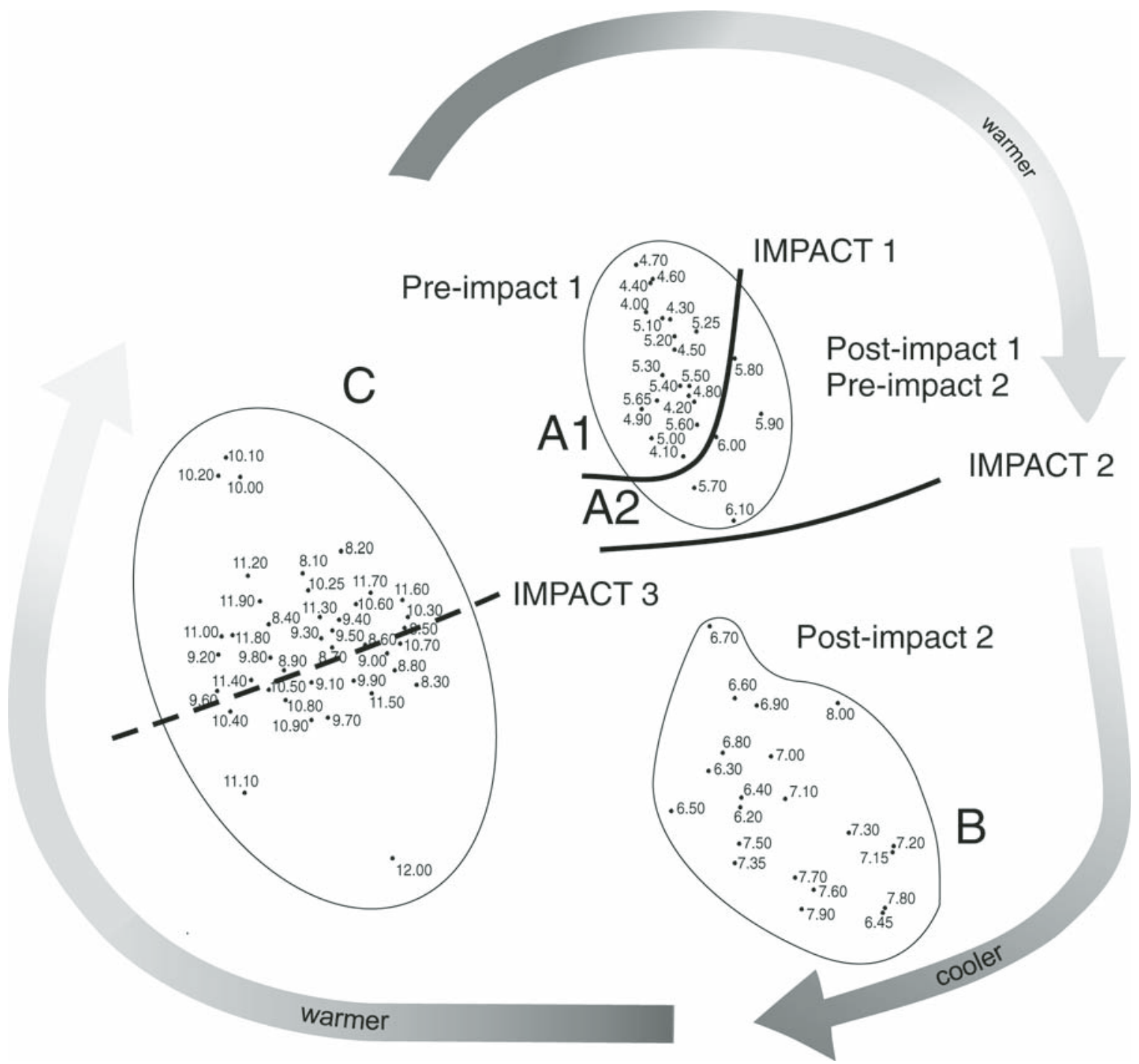

Figure 7. Interpretation of clusters identified in the dendrogram (Fig. 6) using non-metric multidimensional scaling (nMDS). The ordination by nMDS is an iterative procedure to represent "distance" of samples from a multidimensional space on the base of rank dissimilarities. The plot has no defined scale. The stress value (0.13) represents the distortion involved in compressing the data to a small number of dimensions; stress $<0.2$ in 2D means a useful representation of data (Kruskal, 1977; Field et al., 1982). In this study, the line IMPACT 1, which corresponds to the Ir anomaly at $5.61 \mathrm{msl}$, allows us to subdivide cluster A into subcluster A1 (pre-impact 1) and subcluster A2 (postimpact 1 to pre-impact 2). The most significant feature recognized in the nMDS plot is the line IMPACT 2, which corresponds to the Ir anomaly at $6.17 \mathrm{msl}$. This line clearly separates cluster A from cluster B, corresponding to CI-I and CI-II, respectively. According to the multivariate statistical results, any significant change in planktonic foraminiferal assemblages took place across the Ir anomaly at $10.28 \mathrm{msl}$ (dotted line IMPACT 3 ). The shaded bands with arrows indicate the temperature water gradient based on climate curve.

and Popigai microkrystite layers (both at $35.43 \mathrm{Ma}$ ) falls within chron C16n.1n, with an interpolated magnetochronologic age of 35.426 Ma (Miller et al., 2007; Pusz et al., this volume). This is consistent with published radiometric ages ranging from 35.3 to 35.7 Ma (Glass et al., 1982; Obradovich et al., 1989; Bottomley et al., 1997; Horton and Izett, 2005). According to the planktonic foraminiferal biostratigraphy provided at the ODP Site 1090 by Galeotti et al. (2002), the microtektite and microkrystite layers fall in the upper part of the Globigerinatheka indexGloborotaloides suteri (AP11-AP12) zones of Stott and Kennett (1990), which would correspond to the upper part of zones P15P16 of Berggren et al. (1995) and in the middle part of zones NP19/20 of Martini (1971), following the nannofossil calcareous biostratigraphy established by Marino and Flores (2002).

According to the magnetobiochronology provided by Poag et al. $(2003,2004)$ for the continuous interval of the Chickahominy 
Formation in the Kiptopeke core hole, which lies conformably above the Chesapeake Bay impact crater, the Chesapeake Bay impact would have taken place in chron $\mathrm{C} 16 \mathrm{n} .2 \mathrm{n}$ and within planktonic foraminiferal zone P15 of Berggren et al. (1995), with an extrapolated age of $35.78 \mathrm{Ma}$. However, the new magnetostratigraphic data from the Massignano GSSP together with those from ODP Holes 689B and 1090B cast reliable doubt on the interpretation of the magnetostratigraphic record of the Kiptopeke core hole, which, as a consequence, needs to be refined.

\section{Planktonic Foraminiferal Overall Trends during the Late Eocene}

The end of the Eocene was a critical interval within the transition from the Eocene "greenhouse" world to the Oligocene "icehouse" world marked by significant evolutionary turnovers of marine biota and changes of oceanographic and atmospheric circulation patterns (Benson, 1975, 1990; Kennett, 1977; Miller et al., 1987, 1991, 2005; Lear et al., 2000, 2008; Zachos et al., 2001; Coxall et al., 2005; Pagani et al., 2005; Tripati et al., 2005; Coxall and Pearson, 2007). Through a study based on planktonic foraminifera assemblages from some Deep Sea Drilling Program (DSDP) sites in the low-latitude Atlantic (Site 363), Pacific (Site 292), and Indian (Site 219) Oceans and a high-latitude South Pacific site (Site 277), Keller (1983) observed that the Eocene to early Oligocene cooling proceeded by pulses separated by relatively stable climate conditions. These pulses were characterized by rapid cooling indicated by the oxygen isotope record, major faunal turnovers, and hiatuses. She identified one of the major pulses in the interval across the transition between planktonic foraminiferal zone P15 and P16 of Berggren and Miller (1988) and Berggren et al. (1995) and observed that this pulse was accompanied by successive replacement of warm middle Eocene surface planktonic foraminiferal species by cooler late Eocene intermediate- and deep-water species. According to Keller (1983), the disappearance of the surface dwellers suggests that in high- and low-latitude oceans, during the planktonic foraminiferal zone P15-P16 interval, significantly cooler temperatures prevailed in the upper $400-500 \mathrm{~m}$ of the water column. Boersma and Premoli Silva (1986) and Keller et al. (1992) pointed out that long-term trend of planktonic foraminifera evolutionary turnover from the middle Eocene into the Oligocene largely involved extinction of warm-water, tropical, surface-dwelling species.

Several authors have speculated about the causes that produced the late Eocene cooling and foraminiferal faunal reorganization. Keller (1983) and Keller et al. (1992) related the late Eocene cooling and water mass reorganization to significant ice-cap development and increased thermal gradients between the equator and the poles, and Berger et al. (1981) observed that cooling phases may have been enhanced by increased albedo. Boersma et al. (1987) explained the reorganization of the planktonic foraminiferal assemblage structures in zone P16 by a shoaling of the nutricline and oxygen minimum layer. Boersma and Premoli Silva (1991) and Hallock et al. (1991) attributed the vari- ations in the structure of the planktonic foraminiferal communities from the late middle Eocene through the middle Oligocene to reduced temperatures, shoaling of the thermocline, and increased delivery of nutrients to oceanic surface waters. These changes produced a contraction of the trophic resource regional gradient and reduction of oligotrophic and warm surface-water habitats (Hallock, 1987). According to Coxall and Pearson (2007), the extinction at and near the Eocene-Oligocene boundary might therefore have been due to rapid environmental change and cooling, and it may also have been influenced by changing water mass stratification and patterns of biological productivity.

The discovery of some bolide-impact craters and associated breccias, ejecta horizons, and cosmic signatures (e.g., Montanari et al., 1993, 1998; Clymer et al., 1995, 1996; Langenhorst and Clymer, 1996; Poag and Aubry, 1995; Koeberl et al., 1996; Bottomley et al., 1997; Farley et al., 1998; Pierrard et al., 1998; Liu et al., 2000; Kyte, 2001; Kyte and Liu, 2002; Poag et al., 2002, 2003, 2004; Bodiselitsch et al., 2004) in the late Eocene has led to speculation that the late Eocene impact events may have played an important role related to the biotic turnover and the deterioration of the global climate at the end of the Eocene Epoch, even if their effects on the climate and on the biosphere are still not completely clear (e.g., Keller, 1986; Brinkhuis and Coccioni, 1995; Coccioni et al., 2000; Vonhof et al., 2000; Poag et al., 2002, 2003, 2004; Spezzaferri et al., 2002; Bodiselitsch et al., 2004).

Minor extinction episodes and assemblage shifts among planktonic (e.g., Keller, 1986; Coccioni et al., 2000; Spezzaferri et al., 2002) and benthic (Poag et al., 2004) foraminifera, dinocysts (Brinkhuis and Coccioni, 1995; Vonhof et al., 2000), and stable oxygen and carbon isotope excursions associated with the impact-ejecta horizons at several sites (Vonhof et al., 2000; Poag et al., 2002, 2003, 2004; Bodiselitsch et al., 2004; Pusz et al., 2006, 2007, this volume; Miller et al., 2007) have been taken as evidence for global-scale short- and long-term environmental disturbance related to the impacts. According to Coxall and Pearson (2007), it seems unlikely that the impacts had a major influence on Earth's biosphere at the Eocene-Oligocene boundary, and they have to be ruled out as a possible cause of the climatic transition. It is possible, however, that climatic disruption caused by atmospheric dust loading associated with the late Eocene impacts, coupled with an ice-albedo feedback mechanism that amplified impact-induced climatic cooling, may have contributed to global cooling in the run-up to the Eocene-Oligocene transition.

\section{Late Eocene Impact-Induced Environmental Perturbations, Including Climate and Water Mass Structure Changes?: Evidence from the Massignano GSSP}

Several lines of evidence from nannofossil and foraminiferal assemblages (e.g., Keller, 1983; Quilty, 2001; Persico and Villa, 2004; Coccioni et al., 2000; Spezzaferri et al., 2002), dinoflagellate cyst palynology (e.g., Brinkhuis, 1992; Coccioni et al., 2000), clay mineralogy (e.g., Diester-Haass et al., 1996; Ehrmann, 1997), oxygen isotopes (e.g., Kennett and Stott, 1990; Miller et al., 1992; 
Vonhof et al., 2000; Bohaty and Zachos, 2003; Poag et al., 2003, 2004; Bodiselitsch et al., 2004; Pusz et al., 2007, this volume), and environmental magnetism (Sagnotti et al., 1998; Jovane et al., 2004) indicate that the major cooling event at the EoceneOligocene boundary was predated by distinct late Eocene cooling pulses, separated by relatively stable warming phases.

Our data show that the late Eocene impact events recorded in the 4-12 msl segment of the Massignano GSSP had no dramatic effects on planktonic foraminifera. However, acting as forcing factors, they induced some environmental perturbations and may have contributed to noticeable climate changes superimposed on the general late Eocene cooling trend.

Based on field evidence (Coccioni et al., 1988) and on the redistribution of extraterrestrial iridium (Huber et al., 2001) at Massignano, we exclude the effect of bioturbation and the resultant vertical displacement of biostratigraphic and paleoclimatic events. Accordingly, the paleoclimatic trend at Massignano can be considered uncorrupted.

The thermocline is the one of the main features responsible for partitioning of the water column and therefore of the vertical distribution of planktonic organisms, especially foraminifera. Either generally warmer surface water or the presence of a deeper thermocline quantitatively favors shallow and warm-water dwellers, while a shallower thermocline quantitatively favors deeperdwelling and cool-water forms (e.g., Kennett and Barker, 1990).

The generally high abundance of cool- and deep-water species, the low abundances of warm and temperate forms, and the climatic curve from the 4-12 msl segment indicate that the studied interval was characterized by generally cool conditions (Fig. 5), a relatively shallow thermocline, as deduced by the generally high abundances of cool- and deep-water dwellers, and consequently a reduced surface-layer thickness.

Within a time of global cooling, however, abundance variations of the recognized paleoclimatic species and groups document different climate conditions throughout the studied segment at Massignano. Relatively warmer conditions (CI-I) occurred from the base of the studied segment up to the Chesapeake Bay impact event, then relatively coolest conditions (CI-II) persisted for a few hundreds of thousands of years, and finally relatively less cool conditions (CI-III) developed up to the top of the segment (Fig. 5). The statistical treatment of our data corroborates the paleoclimatic trend detected by the fluctuations of the planktonic foraminiferal climatic indices (Fig. 7). Based on our observations, we interpret lines IMPACT 1 and IMPACT 2 in the nMDS plot to represent the temperature gradient (Fig. 7), and we relate the gaps between subcluster $\mathrm{A} 1$ and subcluster $\mathrm{A} 2$ and between subcluster A2 and cluster B to a prevailing warming pulse and a cooling episode after the Popigai and Chesapeake Bay impact events, respectively.

Both the Popigai and Chesapeake Bay impacts liberated energy, probably equivalent to some 10 million megatons of TNT (trinitrotoluene) (Montanari and Koeberl, 2000). These impacts may have had some short-term effects on the environment by injecting dust into the atmosphere, inducing acid rain, cooling, and inhibiting photosynthesis (e.g., Gerstl and Zardecki, 1982; Toon et al., 1994; Kring, 2000).

A slight decrease in abundance of globigerinathekids, which have a symbiotic life strategy (Boersma et al., 1987; Pearson et al., 1993), took place just after the Popigai impact and might have been related to increased water turbidity and/or inhibition of photosynthesis following the impact event itself, which prevented the proliferation of algal symbionts (Figs. 4 and 5). Acarininids are also known as symbiont-bearing species (Coxall et al., 2000), but they are very rare throughout the studied interval (Figs. 4 and 5), and it was not possible to verify their decrease in abundance after the impact events. The recognized distinct opposite trends of the low-oxygen-tolerant chiloguembelinids and pseudohastigerinids may indicate enhanced competition between them during times of environmental stress. There was a slight reduction in the number of chiloguembelinids after the second impact event, which may reflect a very moderate enrichment of $\mathrm{O}_{2}$ in the water masses (Figs. 4 and 5).

At Massignano, an increase in productivity in surface waters across the Popigai and Chesapeake Bay impact intervals persisting for $\sim 137$ k.y. might be inferred from a strong abundance increase of the cosmopolitan, calcareous dinoflagellate species Thalassiphora pelagica, which is interpreted to be a cold-water or productivity indicator (Coccioni et al., 2000). In fact, this species is known to be associated with anoxic sediments (e.g., Köthe, 1990) and with the major cooling event recorded worldwide in the early Oligocene (Brinkhuis and Biffi, 1993; Zachos et al., 1996).

Changes in ventilation and flushing at the seafloor, reflecting significant reorganization of the water mass structure after the Popigai and Chesapeake Bay impact events, might be indicated by sudden changes in sediment color (e.g., Coccioni et al., 2000; Spezzaferri et al., 2002) (Figs. 2-5).

Quantitative changes in the planktonic foraminiferal assemblages indicate a slight warming pulse $\sim 5$ k.y. after the deposition of the impactoclastic layer related to the Popigai impact. This discrete pulse is followed by alternating cooler and warmer intervals. However, as highlighted by subcluster A2, the interval between the Popigai and Chesapeake Bay impacts, lasting for $\sim 77$ k.y., was characterized by prevailing warmer condition compared to the conditions encountered prior to the first impact (Figs. 5 and 7).

The Chesapeake Bay impact took place within a following cooling episode. Bodiselitsch et al. (2004) documented a negative shift in bulk carbonate $\delta^{18} \mathrm{O}$ and $\delta^{13} \mathrm{C}$ close to the Ir-rich level at $6.17 \mathrm{msl}$ compared to the continuously decreasing trend over the entire Massignano section. According to these authors, despite the fact that oxygen isotope values at Massignano are clearly diagenetically influenced, the negative excursion of $\delta^{18} \mathrm{O}$ might provide evidence of a short warming pulse. After the Chesapeake Bay impact, an enhanced cooling (CI-II) interval started (Fig. 5; cluster B in Figs. 6 and 7), as testified by the increase in abundance of cool and cool-temperature water species and groups. This change in abundance occurred along with a concurrent decrease in abundance of warm and warm-temperature 
water species and groups, which reveals a contraction of the mixed and surface layers, and consequent decrease of niches in the warmer surface water. This relatively long-term cooling episode lasted for $\sim 247$ k.y. and was accompanied by a shallowing of the thermocline, which occurred in the interval spanning the transition between planktonic foraminiferal zones P15 and P16 of Berggren et al. (1995), which is in the lower part of zone E15 of Berggren and Pearson (2006), and it may have been related to the cooling pulse identified by Keller (1983) in the same biostratigraphic interval.

Oxygen isotope records at ODP Hole 689B indicate accelerated climatic cooling, possibly combined with increased surface-water productivity deduced by $\delta^{13} \mathrm{C}$ data and calcareous dinocyst abundances, coinciding with the two nearly contemporaneous impact events (Vonhof et al., 2000). The relatively long duration of the cooling pulse that followed the impact events led Vonhof et al. (2000) to suggest that a feedback mechanism, such as a global albedo increase due to extended snow and ice cover, sustained the initial impact-induced changes. We agree with this hypothesis to explain the enhanced cooling following the Chesapeake Bay impact and corresponding to interval CI-II, where a rapid increase of $\delta^{13} \mathrm{C}$ and $\delta^{18} \mathrm{O}$ values occurs (Bodiselitsch et al., 2004) together with an increase in abundance of Thalassiphora pelagica (Coccioni et al., 2000).

The enhanced cooling terminated within the middle part of chron $\mathrm{C} 15 \mathrm{r}$ and the lowermost part of planktonic foraminiferal zone P16 of Berggren et al. (1995), which is in the lower part of zone E15 of Berggren and Pearson (2006) (Fig. 5). From there on, climate conditions intermediate (CI-III) between the warmest conditions (CI-I) and the coolest conditions (CI-II), as recorded through the studied segment, developed and persisted (Fig. 5), as also evidenced by cluster C (Figs. 6 and 7).

The third impact, which lies within the CI-III interval, led to an enhanced cooling that was followed after $\sim 15 \mathrm{k}$.y. by a subsequent return to less cool conditions, which extend up to the top of the studied segment (Fig. 5).

However, this impact does not appear to have produced significant environmental perturbations, as evidenced by the unimportant fluctuations of the planktonic foraminiferal assemblages (Figs. 5 and 7). According to Bodiselitsch et al. (2004), negative excursions in bulk carbonate $\delta^{18} \mathrm{O}$ and $\delta^{13} \mathrm{C}$ occur close to the Ir-rich level at $10.28 \mathrm{msl}$, which might indicate a sudden warming pulse caused by this impact event. Again, on the basis of carbon and oxygen isotope ratio data, it seems that seawater temperature did not remarkably change in between the two last Ir-enhanced intervals at Massignano (Bodiselitsch et al., 2004). However, the average $\delta^{13} \mathrm{C}$ values differ somewhat between the two regions, which could indicate an incursion of colder, more vigorous bottom waters and an increase of biomass and productivity during this time span as seen in the deep-water benthic foraminifera faunal turnover recognized in the same interval by Coccioni and Galeotti (2003).

Based on this line of evidence, the climatic effects of the late Eocene impact events as documented at Massignano therefore appear to be not univocal. In fact, it seems that the Popigai impact was followed by a prevailing warming pulse, whereas the other two impact events were followed by an enhanced cooling.

It is well known that the environmental and the biological effects of an impact event must be evaluated in terms of impactor size as well as in the context in which it occurs in terms of location and target rocks (e.g., Kring, 2000). The Popigai and Chesapeake Bay impactors are estimated to have been $5 \mathrm{~km}$ (Tagle and Claeys, 2004) and $3.2 \mathrm{~km}$ (Collins and Wünnemann, 2005) in diameter, respectively. The Popigai impact occurred on the continent, whereas the Chesapeake Bay impact took place on the continental shelf. The target rocks of the Popigai structure are generally granitic gneisses overlain by sandstone and carbonates (Bottomley et al., 1997) produced by the impact of an ordinary chondrite body (Masaitis and Raikhlin, 1986). The Chesapeake Bay impact structure is developed in a mixed-target substrate composed of granitoids and metasedimentary rocks overlain by dominantly siliciclastic, sedimentary rocks (Koeberl et al., 1996; Poag et al., 2002). According to Bodiselitsch et al. (2004), the Ir anomaly at $10.28 \mathrm{msl}$ may be also derived from an impact into a continental shelf, similar to the Chesapeake Bay impact. Kent et al. (2003) suggested that release of methane hydrates from mechanical disruption of sediments as a result of an impact could cause a greenhouse effect, which is revealed by negative excursions in the carbon and oxygen isotope records. In view of this, Bodiselitsch et al. (2004) speculated that the warm pulses at 6.17 and $10.28 \mathrm{msl}$ could be due to the release of large amounts of seafloor methane hydrate during and after the last two impact events that induced the negative excursions in $\delta^{13} \mathrm{C}$ in both Ir-enhanced regions. A similar hypothesis has been evaluated by Pusz et al. (2007, this volume) on the basis of the significant $\delta^{13} \mathrm{C}$ negative excursion in both bulk and benthic foraminiferal carbonate coincident with the impact-ejecta horizons at ODP Site 1090 and DSDP Site 612. According to our data, a release of methane large enough to induce a greenhouse scenario can be evaluated only for the Popigai impact, which was followed by a prevailing warming pulse.

On the basis of the relationship among the Chesapeake Bay and Montagnais impacts and the oxygen isotope (inferred paleotemperature) and extraterrestrial ${ }^{3} \mathrm{He}$ curves, Poag et al. (2002, 2003 , 2004) stated that the general cooling trend from the middle Eocene to the early Oligocene was interrupted by long- and shortterm warming episodes. These episodes, possibly triggered by a multiple impact event, would have released greenhouse gases into the atmosphere during the late Eocene comet or asteroid shower and would have been superimposed on an overall cooling trend. Poag et al. (2002, 2003) proposed that this impact-generated greenhouse warming may have postponed a pending late Eocene mass extinction until the early Oligocene. More specifically, Poag et al. $(2003,2004)$ recognized three distinct subpulses of warm climate, $\mathrm{W}-1$ to $\mathrm{W}-3$, that followed the Chesapeake Bay impact and are indicated by lower oxygen and carbon isotope ratio values. According to these authors, the warm pulses correlate with an interval of increased ${ }^{3} \mathrm{He}$ at Massignano. In particular, subpulse W-1 correlates with chron C16n.2n and the lower part of chron C16n.1r and falls within zone P15 of Berggren et al. 
(1995), and subpulse W-2 coincides with chron C16n.1n and the lower two-thirds of chron $\mathrm{C} 15 \mathrm{r}$ and lies in the transition between planktonic foraminiferal zones P15 and P16 of Berggren et al. (1995). However, as reported in "High-Resolution Impact Stratigraphy, Geochronology, and Magnetochronology at Massignano: Implications for Global Correlation," the correlation of these subpulses with the magnetostratigraphy at Kiptopeke core hole has to be refined.

At Massignano, Bodiselitsch et al. (2004) correlated the Ir anomalies at 6.17 and $10.28 \mathrm{msl}$, respectively, with warm subpulses W-1 and W-2 of Poag et al. (2003, 2004). Following this and according to the refined magnetobiostratigraphy provided by Jovane et al. (2007, this volume), the warm subpulse W-1 would fall in the uppermost part of chron C16n.1n and in the upper part of planktonic foraminiferal zone P15 Berggren et al. (1995), which is in the lower part of zone E15 Berggren and Pearson (2006). Warm subpulse W-2 would lie in the middle part of chron $\mathrm{C} 15 \mathrm{n}$ and in the lower part of planktonic foraminiferal zone P16 Berggren et al. (1995), which is in the middle part of zone E15 Berggren and Pearson (2006) (Figs. 4 and 5). However, according to the magnetobiostratigraphy currently available for the Massignano GSSP and our climatic curve, correlation of the warm subpulse W-2 of Poag et al. (2003, 2004) with the warm pulse recognized at Massignano in the interval between 8.1 and $8.4 \mathrm{msl}$ and well constrained in the middle part of chron $\mathrm{C} 15 \mathrm{r}$ and in the lowermost part of planktonic foraminiferal zone P16 of Berggren et al. (1995) (Fig. 5) would be more consistent. Moreover, it fits well with the prominent negative value of $\delta^{18} \mathrm{O}$ recorded at $8.2 \mathrm{msl}$ by Bodiselitsch et al. (2004).

The main climatic episodes documented at Massignano by the abundance variations of the planktonic foraminiferal paleoclimatic indices are largely mirrored by the alternating relatively warm and humid intervals with cold and dry intervals recognized in the late Eocene on a global scale through high-resolution environmental magnetic studies carried out at CIROS-1 drill core from McMurdo Sound (Antarctica) (Sagnotti et al., 1998) and at Massignano (Jovane et al., 2004). The existence of alternating warm and cool intervals at the Eocene-Oligocene transition has also been revealed through high-resolution paleoclimatic analyses of calcareous nannofossils at the Southern Ocean ODP Holes 689D (Maud Rise, Weddell Sea, Antarctica) and 744A (Kerguelen Plateau, Antarctica) (Persico and Villa, 2004). In particular, from the uppermost part of chron C16n.2n up to the lowermost part of chron $\mathrm{C} 13 \mathrm{r}$, three warm intervals alternate with two cool intervals. These intervals are well constrained by the magnetostratigraphy provided by Roberts et al. (2003) and Florindo and Roberts (2005). We can point out that in terms of magnetobiostratigraphy, these intervals fit very well with the climatic intervals we recognize at Massignano, including the cool intervals detected at the transition between chron $\mathrm{C} 16 \mathrm{n} .1 \mathrm{r}$ and chron C16n.1n, which would be correlated with the cooling recorded between 5.20 and $5.30 \mathrm{msl}$.

The consequences of the late Eocene impacts seem to be much smaller than those seen following the Chicxulub impact at the Cretaceous-Paleogene boundary (e.g., Alvarez et al., 1980; Kring, 2007), which led to the well-known mass extinction event (e.g., Sepkoski, 1986).

Further high-resolution studies, possibly on millennial time scales, from high-quality sediment archives should provide reliable data sets to document and to improve understanding of impact-induced biotic and climatic changes and to more accurately correlate them with marine and continental records.

\section{CONCLUSIONS}

The three late Eocene impact events recorded in the Massignano GSSP had no abrupt, dramatic effects on planktonic foraminifera. However, the high-resolution quantitative study and the multivariate statistical analysis revealed noteworthy changes in the assemblages occurring after the impacts. Acting as forcing factors, these impacts induced some environmental perturbations and may have contributed to significant climate changes superimposed on the general late Eocene cooling trend. These climate changes displayed different features at each impact event, probably due to the context in which each occurred (e.g., target rocks).

In particular, the first two closely spaced impacts related to the Popigai and Chesapeake Bay craters revealed significant changes in the water mass structure, in terms of stratification and trophic resources, associated with some warming and cooling episodes that took place within chron $\mathrm{C} 16 \mathrm{n} .1 \mathrm{n}$ and chron $\mathrm{C} 15 \mathrm{r}$ and at the transition between planktonic foraminiferal zones P15 and P16 of Berggren et al. (1995).

The prevailing warming pulse recognized after the Popigai impact might have been due to greenhouse effects produced by injection of $\mathrm{CO}_{2}$ into the atmosphere and/or the release of methane hydrate after the impact itself. The relatively long duration of the enhanced cooling following the Chesapeake Bay impact suggests that this impact induced a progressive cooling and triggered a feedback mechanism that sustained the initial impact-induced changes. Similar patterns of climatic excursions reported across the equivalent impact-ejecta horizons in the Pacific, Indian, Atlantic-Caribbean, and Southern Oceans, as well as in Antarctica, indicate that climate changes recorded at Massignano seem to have had a global, rather than local or regional, significance.

\section{ACKNOWLEDGMENTS}

The authors warmly thank F. Hilgen, K.G. Miller, C. Koeberl, and A.E. Pusz for their criticism and helpful suggestions, which greatly improved the manuscript. We also thank Carla Bucci for technical support. This is publication 24 of the Centro di Geobiologia of Urbino University.

\section{REFERENCES CITED}

Alvarez, L.W., Alvarez, W., Asaro, F., and Michel, H.V., 1980, Extraterrestrial cause for the Cretaceous-Tertiary extinction: Science, v. 208, p. 10951108, doi: 10.1126/science.208.4448.1095. 
Barrera, E., and Huber, B.T., 1991, Paleogene and early Neogene oceanography of the southern Indian Ocean; Leg 119 foraminifer stable isotope results, in Larsen, B., and Baldauf, J.G., et al., Proceedings of the Ocean Drilling Program, Scientific Results, Volume 119: College Station, Texas, Ocean Drilling Program, p. 736-774.

Barrera, E., and Huber, B.T., 1993, Eocene to Oligocene oceanography and temperatures in the Antarctic Indian Ocean, in Kennett, J.P., and Warnke, D.A., eds., The Antarctic Paleoenvironment: A Perspective on Global Change, Part II. Antarctic Research Series: Washington, D.C., American Geophysical Union, v. 60, p. 49-65.

Benson, R., 1975, The origin of the psycrosphere as recorded in changes of deep-sea ostracods assemblages: Lethaia, v. 8, p. 69-83, doi: 10.1111/ j.1502-3931.1975.tb00919.x.

Benson, R.H., 1990, Ostracoda and the discovery of global Cainozoic palaeoceanographical events, in Whatley, R., and Maybury, C., eds., Ostracoda and Global Events: London, Chapman and Hall, p. 41-58.

Berger, W.H., Vincent, E., and Thierstein, H.R., 1981, The deep sea record: Major steps in Cenozoic ocean evolution: Society of Economic Paleontologists and Mineralogists (SEPM) Special Publication 32, p. 489-504.

Berggren, W.A., and Miller, K.G., 1988, Paleogene tropical planktonic foraminiferal biostratigraphy and magnetobiochronology: Micropaleontology, v. 34, p. 362-380, doi: 10.2307/1485604.

Berggren, W.A., and Miller, K.G., 1989, Cenozoic bathyal and abyssal calcareous benthic foraminiferal zonation: Micropaleontology, v. 35, p. 308-320, doi: $10.2307 / 1485674$.

Berggren, W.A., and Pearson, P.N., 2006, Tropical to subtropical planktonic foraminiferal zonation of the Eocene and Oligocene, in Pearson, P.N., Olsson, R.K., Huber, B.T., Hemleben, Ch., and Berggren, W.A., eds., Atlas of Eocene Planktonic Foraminifera: Cushman Foundation for Foraminiferal Research, Special Publication 41, Greenville, North Carolina, p. 29-40.

Berggren, W.A., Kent, D.V., Swisher, C.C., III, and Aubry, M.-P., 1995, A revised Cenozoic geochronology and chronostratigraphy, in Berggren, W.A., Kent, D.V., Swisher, C.C., III, Aubry, M.-P., and Hardenbol, J., eds., Geochronology, Time Scales, and Global Stratigraphic Correlation: SEPM (Society for Sedimentary Geology) Special Publication 54, p. 129-212.

Bice, D., and Montanari, A., 1988, Magnetic stratigraphy of the Massignano section across the Eocene/Oligocene boundary, in Premoli Silva, I., Coccioni, R., and Montanari, A., eds., The Eocene-Oligocene Boundary in the Marche-Umbria Basin (Italy): Aniballi, Ancona, International Subcommission on Paleogene Stratigraphy, Special Publication, p. 111-117.

Blow, W.H., 1969, Late middle Eocene to Recent planktonic foraminiferal biostratigraphy, in Bronnimann, P., and Renz, H.H., eds., Proceedings of the First International Conference on Planktonic Microfossils (Geneva, 1967): Leiden, E.J. Brill, p. 199-421.

Blow, W.H., 1979, The Cenozoic Globigerinida: A study of the morphology, taxonomy, evolutionary relationships and the stratigraphical distribution of some Globigerinida (mainly Globigerinacea), Volume 3: Leiden, E.J. Brill, 1413 p.

Bodiselitsch, B., Montanari, A., Koeberl, C., and Coccioni, R., 2004, Delayed climate cooling in the late Eocene caused by multiple impacts: Highresolution geochemical studies at Massignano, Italy: Earth and Planetary Science Letters, v. 223, p. 283-302, doi: 10.1016/j.eps1.2004.04.028.

Boersma, A., and Premoli Silva, I., 1986, Terminal Eocene events-Planktonic foraminifera and isotopic evidence, in Pomerol, C., and Premoli Silva, I., eds., Terminal Eocene Events: Development in Paleontology and Stratigraphy, Elsevier, Amsterdam, p. 213-224.

Boersma, A., and Premoli Silva, I., 1991, Distribution of Paleogene planktonic foraminifera: Analogies with the Recent?: Palaeogeography, Palaeoclimatology, Palaeoecology, v. 83, p. 29-48, doi: 10.1016/0031-0182(91) 90074-2.

Boersma, A., Shackleton, N.J., Hall, M.A., and Given, Q., 1979, Carbon and oxygen isotope records at DSDP Site 384 (North Atlantic) and some Paleocene paleotemperature and carbon isotope variations in the Atlantic Ocean, in Tucholke, B.E., Vogt, P.R., et al., Initial Reports of the Deep Sea Drilling Project, Volume 43: Washington, D.C., U.S. Government Printing Office, p. 695-715.

Boersma, A., Premoli Silva, I., and Shackleton, N.J., 1987, Atlantic Eocene planktonic foraminiferal paleohydrographic indicators and stable isotope paleoceanography: Paleoceanography, v. 3, p. 287-331.

Bohaty, S.M., and Zachos, J.C., 2003, Significant Southern Ocean warming event in the late middle Eocene: Geology, v. 31, p. 1017-1020, doi: 10.1130/G19800.1.
Bottomley, R., Grieve, R., York, D., and Masaitis, V., 1997, The age of the Popigai impact event and its relation to events at the Eocene/Oligocene boundary: Nature, v. 388, p. 365-368, doi: 10.1038/41073.

Brinkhuis, H., 1992, Late Paleogene dinoflagellate cysts with special reference to the Eocene/Oligocene boundary, in Prothero, D.R., and Berggren, W.A., eds., Eocene-Oligocene Climatic and Biotic Evolution: Princeton, New Jersey, Princeton University Press, p. 327-340.

Brinkhuis, H., and Biffi, U., 1993, Dinoflagellate cyst stratigraphy of the Eocene/Oligocene transition in central Italy: Marine Micropaleontology, v. 22, p. 131-183, doi: 10.1016/0377-8398(93)90007-K.

Brinkhuis, H., and Coccioni, R., 1995, Is there a relation between dinocysts changes and iridium after all? Preliminary results from the Massignano section, in Montanari, A., and Coccioni, R., eds., The Effects of Impacts on the Atmosphere and Biosphere with Regard to Short- and Long-Term Changes: Abstracts and Field Trips: Ancona, Italy, European Science Foundation, p. 40.

Cande, S.C., and Kent, D.V., 1992, A new geomagnetic polarity time scale for the Late Cretaceous and Cenozoic: Journal of Geophysical Research, v. 97, p. 13,917-13,951, doi: 10.1029/92JB01202.

Cande, S.C., and Kent, D.V., 1995, Revised calibration of the geomagnetic polarity time scale for the Late Cretaceous and Cenozoic: Journal of Geophysical Research, v. 100, p. 6093-6095, doi: 10.1029/94JB03098.

Channell, J.E.T., Galeotti, S., Martin, E., Billups, K., Scher, H.D., and Stoner, J.S., 2003, Eocene to Miocene magnetostratigraphy, biostratigraphy, and chemostratigraphy at ODP Site 1090 (sub-Antarctic South Atlantic): Geological Society of America Bulletin, v. 115, p. 607-623, doi: 10.1130/ 0016-7606(2003)115<0607:ETMMBA>2.0.CO;2.

Cita, M.B., Vergnaud-Grazzini, C., Robert, C., Chamley, H., Ciaranfi, N., and D'Onofrio, S., 1977, Paleoclimatic record of a long deep sea core from the Eastern Mediterranean: Quaternary Research, v. 8, p. 205-235, doi: 10.1016/0033-5894(77)90046-1.

Claeys, P., 2007, Cause(s) of the elevated bombardment in the late Eocene: Eos (Transactions, American Geophysical Union), v. 88, no. 52, Fall Meeting supplement, abstract U21E-01.

Clarke, K.R., and Warwick, R.M., 1994, Change in Marine Communities: An Approach to Statistical Analysis and Interpretation: Plymouth, Plymouth Marine Laboratory, $144 \mathrm{p}$.

Clifford, H.T., and Stephenson, W., 1975, An Introduction to Numerical Classification: New York, Academic Press, 229 p.

Clymer, A.K., Bice, D.M., and Montanari, A., 1995, Shocked quartz in the late Eocene: Bolide impact evidence from Massignano, Italy, in Montanari, A., and Coccioni, R., eds., The Effects of Impacts on the Atmosphere and Biosphere with Regard to Short- and Long-Term Changes: Abstracts and Field Trips: Ancona, Italy, European Science Foundation, p. 60-61.

Clymer, A.K., Bice, D.M., and Montanari, A., 1996, Shocked quartz from the late Eocene: Impact evidence from Massignano, Italy: Geology, v. 24, p. 483-486, doi: 10.1130/0091-7613(1996)024<0483:SQFTLE >2.3.CO;2.

Coccioni, R., and Galeotti, S., 2003, Deep-water benthic foraminiferal events from the Massignano Eocene/Oligocene boundary stratotype section and point (central Italy): Biostratigraphic, paleoecologic, and paleoceanographic implications, in Prothero, D.R., Ivant, L.C., and Nesbitt, E., eds., From Greenhouse to Icehouse: The Marine Eocene-Oligocene Transition: New York, Columbia University Press, p. 438-452.

Coccioni, R., Monaco, P., Monechi, S., Nocchi, M., and Parisi, G., 1988, Biostratigraphy of the Eocene/Oligocene boundary at Massignano (Ancona, Italy), in Premoli Silva, I., Coccioni, R., and Montanari, A., eds., The Eocene-Oligocene Boundary in the Marche-Umbria Basin (Italy): Aniballi, Ancona, International Subcommission on Paleogene Stratigraphy, Special Publication, p. 59-80.

Coccioni, R., Basso, D., Brinkhuis, H., Galeotti, S., Gardin, S., Monechi, S., and Spezzaferri, S., 2000, Marine biotic signals across a late Eocene impact layer at Massignano, Italy: Evidence for long-term environmental perturbations?: Terra Nova, v. 12, p. 258-263, doi: 10.1046/ j.1365-3121.2000.00305.x.

Collins, G.S., and Wünnemann, K., 2005, How big was the Chesapeake Bay impact? Insight from numerical modelling: Geology, v. 33, p. 925-928, doi: $10.1130 / \mathrm{G} 21854.1$

Coxall, H.K., and Pearson, P.N., 2007, The Eocene-Oligocene transition, in Williams, M., Hayward, A., Gregory, J., and Schmidt, D., eds., Deep Time Perspectives on Climate Change: Marrying the Signal from Computer Models and Biological Proxies: The Micropalaeontological Society Special Publication 2, p. 351-387. 
Coxall, H.K., Pearson, P.N., and Shackleton, N.J., 2000, Hantkeninids depth adaptation: An evolving life strategy in a changing ocean: Geology, v. 28, p. 87-90, doi: 10.1130/0091-7613(2000)28<87:HDAAEL >2.0.CO;2.

Coxall, H.K., Wilson, P.A., Pälike, H., Lear, C.H., and Backman, J., 2005, Rapid stepwise onset of Antarctic glaciation and deeper calcite compensation in the Pacific Ocean: Nature, v. 433, p. 53-57, doi: 10.1038/nature03135.

Diester-Haass, L., Robert, C., and Chamley, H., 1996, The Eocene-Oligocene preglacial-glacial transition in the Atlantic sector of the Southern Ocean (ODP Site 690): Marine Geology, v. 131, p. 123-149, doi: 10.1016/0025-3227 (95)00174-3

Douglas, W., and Savin, S.M., 1978, Oxygen isotopic evidence for the depth stratification of Tertiary and Cretaceous planktic foraminifera: Marine Micropaleontology, v. 3, p. 175-196, doi: 10.1016/0377-8398(78)90004-X.

Ehrmann, W.U., 1997, Smectite concentrations and crystallinities: Indications for Eocene age of glaciomarine sediments in the CIROS-1 drill hole, McMurdo Sound, Antarctica, in Ricci, C.A., ed., The Antarctic Region, Geological Evolution and Processes: Siena, Museo Nazionale dell'Antartide, p. 771-780.

Farley, K.A., 2007, The late Eocene extraterrestrial dust event: Comet or asteroid shower?, in Montanari, A., Koeberl, C., Coccioni, R., and Hilgen, F., eds., The Late Eocene Earth: Hot House, Ice House, and ImpactsAbstract with Program and Field Trip Guide: Ancona, Italy, Osservatorio Geologico di Coldigioco Frontale di Apiro, Geological Society of America Penrose Conference, p. 22-23.

Farley, K.A., Montanari, A., Shoemaker, E.M., and Shoemaker, C.S., 1998, Geochemical evidence for a comet shower in the late Eocene: Science, v. 280 , p. $1250-1253$, doi: 10.1126/science. 280.5367 .1250 .

Field, J.G., Clarke, K.R., and Warwick, R.M., 1982, A practical strategy for analysing multispecies distribution patterns: Marine Ecology Progress Series, v. 8, p. 37-52, doi: 10.3354/meps008037.

Florindo, F., and Roberts, A.P., 2005, Eocene-Oligocene magnetobiochronology of ODP Sites 689 and 690, Maud Rise, Weddell Sea, Antarctica: Geological Society of America Bulletin, v. 117, p. 46-66, doi: 10.1130/ B25541.1.

Galeotti, S., Coccioni, R., and Gersonde, R., 2002, Middle Eocene-early Pliocene subantarctic planktic foraminiferal biostratigraphy of Site 1090, Agulhas Ridge: Marine Micropaleontology, v. 45, p. 357-381, doi: 10.1016/S0377-8398(02)00035-X.

Gerstl, S.A.W., and Zardecki, A., 1982, Reduction of photosynthetically active radiation under extreme stratospheric aerosol loads, in Silver, L.T., and Schultz, P.H., eds., Geological Implications of Impacts of Large Asteroids and Comets on the Earth: Geological Society of America Special Paper 190, p. 201-210.

Glass, B.P., Dubois, D.L., and Ganapathy, R., 1982, Relationship between an iridium anomaly and the North American microtektite layer in core RC9-58 from the Caribbean Sea, in Boynton, W.V., and Ahrens, T.J., eds., Proceedings of the 13th Lunar and Planetary Science Conference: Journal of Geophysical Research, v. 90, part I, p. D175-D196.

Gradstein, F.M., Ogg, J.G., and Smith, A.G., 2004, A Geologic Time Scale: Cambridge, Cambridge University Press, $589 \mathrm{p}$.

Hallock, P., 1987, Fluctuations in the trophic resource continuum: A factor in global diversity cycles?: Paleoceanography, v. 2, p. 457-471, doi: 10.1029/PA002i005p00457.

Hallock, P., Premoli Silva, I., and Boersma, A., 1991, Similarities between planktonic and larger foraminiferal evolutionary trends through Paleogene paleoceanographic changes: Palaeogeography, Palaeoclimatology, Palaeoecology, v. 83, p. 49-64, doi: 10.1016/0031-0182(91)90075-3.

Haq, B.U., Premoli Silva, I., and Lohman, G.P., 1977, Calcareous plankton paleobiogeographic evidence for major climatic fluctuations in the early Cenozoic Atlantic Ocean: Journal of Geophysical Research, v. 82, p. 3861-3876, doi: 10.1029/JC082i027p03861.

Horton, J.W., and Izett, G.A., 2005, Crystalline-rock ejecta and shocked minerals of the Chesapeake Bay impact structure: The USGS-NASA Langley corehole, Hampton, Virginia, with supplement constraints on the age of the impact, in Horton, J.W., Powars, D.S., and Gohn, G., eds., Studies of the Chesapeake Bay Impact Structure: Reston, Virginia, U.S. Geological Survey, p. E1-E29.

Huber, H., Koeberl, C., King, D.T., Petruny, L.W., and Montanari, A., 2001, Effects of bioturbation through the late Eocene impactoclastic layer near Massignano, Italy, in Buffetaut, E., and Koeberl, C., eds., Geological and Biological Effects of Impact Events: Berlin, Springer-Verlag, p. 197-216.
Jovane, L., Florindo, F., and Dinarès-Turell, J., 2004, Environmental magnetic record of paleoclimate change from the Eocene-Oligocene stratotype section, Massignano, Italy: Geophysical Research Letters, v. 31, p. L15601, doi: 10.1029/2004GL020554.

Jovane, L., Florindo, F., Sprovieri, M., and Pälike, H., 2006, Astronomic calibration of the late Eocene/early Oligocene Massignano section (central Italy): Geochemistry, Geophysics, Geosystems, v. 7, p. Q07012, doi: 10.1029/2005GC001195.

Jovane, L., Sprovieri, M., Florindo, F., Acton, G., Coccioni, R., Dall'Antonia, B., and Dinarès-Turrell, J., 2007, Eocene-Oligocene paleoceanographic changes in the stratotype section, Massignano, Italy: Clues from rock magnetism and stable isotopes: Journal of Geophysical Research, v. 112, p. B11101, doi: 10.1029/2007JB004963.

Jovane, L., Coccioni, R., Marsili, A., and Acton, G., 2009, this volume, The late Eocene greenhouse-icehouse transition: Observations from the Massignano global stratotoype section and point (GSSP), in Koeberl, C., and Montanari, A., eds., The Late Eocene Earth-Hothouse, Icehouse, and Impacts: Geological Society of America Special Paper 452, doi: $10.1130 / 2009.2452(10)$

Keller, G., 1983, Paleoclimatic analyses of middle Eocene through Oligocene planktic foraminiferal faunas: Palaeogeography, Palaeoclimatology, Palaeoecology, v. 43, p. 73-94, doi: 10.1016/0031-0182(83)90049-4.

Keller, G., 1986, Stepwise mass extinctions and impact events late Eocene to early Oligocene: Marine Micropaleontology, v. 10, p. 267-293, doi: 10.1016/0377-8398(86)90032-0.

Keller, G., Macleod, N., and Barrera, E., 1992, Eocene-Oligocene faunal turnover in planktic foraminifera, and Antarctic glaciation, in Prothero, D.R., and Berggren, W.A., eds., Eocene-Oligocene Climatic and Biotic Evolution: Princeton, New Jersey, Princeton University Press, p. 218-244.

Kennett, J.P., 1977, Cenozoic evolution of Antarctic glaciation, the circumAntarctic Ocean, and their impact on global palaeoceanography: Journal of Geophysical Research, v. 82, p. 3843-3860, doi: 10.1029/ JC082i027p03843.

Kennett, J.P., and Barker, P.F., 1990, Latest Cretaceous to Cenozoic climate and oceanographic developments in the Weddell Sea, Antarctica: An oceandrilling perspective, in Barker, P.F., Kennett, J.P., O'Connell, S., and Pisias, N.G., et al., Proceedings of the Ocean Drilling Program, Scientific Results, Volume 113: College Station, Texas, Ocean Drilling Program, p. 937-960.

Kennett, J.P., and Stott, L.D., 1990, Proteus and proto-Oceanus: Ancestral Paleogene oceans as revealed from Antarctic stable isotopic results; ODP Leg 113, in Barker, P.F., Kennett, J.P., O'Connell, S., and Pisias, N.G., et al., Proceedings of the Ocean Drilling Program, Scientific Results, Volume 113: College Station, Texas, Ocean Drilling Program, p. 865-880.

Kent, D.V., Cramer, B.S., Lanci, L., Wang, D., Wright, J.D., and Van der Voo, R., 2003, A case for a comet impact trigger for the Paleocene/Eocene thermal maximum and carbon isotope excursion: Earth and Planetary Science Letters, v. 211, p. 13-26, doi: 10.1016/S0012-821X(03)00188-2.

Koeberl, C., 2007, Late Eocene craters and impactoclastic layers-An overview, in Montanari, A., Koeberl, C., Coccioni, R., and Hilgen, F., eds., The Late Eocene Earth: Hot House, Ice House, and Impacts-Abstract with Program and Field Trip Guide: Ancona, Italy, Osservatorio Geologico di Coldigioco Frontale di Apiro, Geological Society of America Penrose Conference, p. 43-45.

Koeberl, C., Poag, C.W., Reimold, W.H., and Brandt, D., 1996, Impact origin of the Chesapeake Bay structure and the source of the North American tektites: Science, v. 271, p. 1263-1266, doi: 10.1126/science.271.5253.1263.

Köthe, A., 1990, Paleogene dinoflagellates from north West Germany: Geologisches Jahrbuch A, v. 118, 111 p.

Kring, D.A., 2000, Impact events and their effect on the origin, evolution and distribution of life: GSA Today, v. 10, no. 8, p. 1-7.

Kring, D.A., 2007, The Chicxulub impact event and its environmental consequences at the Cretaceous-Tertiary boundary, in Coccioni, R., Monechi, S., and Rampino, M.R., eds., Cretaceous-Paleogene Boundary Events: Palaeogeography, Palaeoclimatology, Palaeoecology, v. 255, p. 4-21.

Kruskal, J.B., 1977, Multidimensional scaling and other methods for discovering structure, in Enslein, K., Ralston, A., and Wilf, H.S., eds., Statistical Methods for Digital Computers: New York, John Wiley, p. 296-339.

Kyte, F.T., 2001, Identification of late Eocene impact deposits at ODP Site 1090, in Gersonde, R., Hodell, D.A., and Blum, P., et al., Proceedings of the Ocean Drilling Program, Scientific Results, Volume 177: College Station, Texas, Ocean Drilling Program, p. 1-9. 
Kyte, F.T., and Liu, S., 2002, Iridium and spherules in late Eocene impact deposits: Houston, Texas, Lunar and Planetary Institute, v. 33, abstract A1981 (CD-ROM).

Langenhorst, F., and Clymer, A.K., 1996, Characteristics of shocked quartz in late Eocene impact ejecta from Massignano (Ancona, Italy): Clues to shock conditions and source crater: Geology, v. 24, p. 487-490, doi: 10.1130/0091-7613(1996)024<0487:COSQIL >2.3.CO;2.

Lear, C.H., Elderfield, H., and Wilson, P.A., 2000, Cenozoic deep-sea temperatures and global ice volumes from $\mathrm{Mg} / \mathrm{Ca}$ in benthic foraminiferal calcite: Science, v. 287, p. 269-272, doi: 10.1126/science.287.5451.269.

Lear, C.H., Bailey, T.R., Pearson, P.N., Coxall, H.K., and Rosenthal, Y., 2008, Cooling and ice growth across the Eocene-Oligocene transition: Geology, v. 36, p. 251-254, doi: 10.1130/G24584A.1.

Liu, S., Kyte, F.T., Glass, B.P., and Gersonde, R., 2000, Upper Eocene spherules at ODP Site 1090B: Meteoritics \& Planetary Science, v. 35, abstract A98-99.

Lowrie, W., and Lanci, L., 1994, Magnetostratigraphy of Eocene/Oligocene boundary sections in Italy: No evidence for short subchrons within chrons 12R and 13R: Earth and Planetary Science Letters, v. 126, p. 247-258, doi: 10.1016/0012-821X(94)90110-4.

Marino, M., and Flores, J.A., 2002, Middle Eocene to early Oligocene calcareous nannofossil stratigraphy at Leg 117 Site 1090: Marine Micropaleontology, v. 45, p. 383-398, doi: 10.1016/S0377-8398(02)00036-1.

Martini, E., 1971, Standard Tertiary and Quaternary calcareous nannoplankton zonation, in Farinacci, A., ed., Proceedings of the Second Planktonic Conference, Rome 1970: Rome, Tecnoscienza, v. 2, p. 739-785.

Masaitis, V.L., and Raikhlin, A.I., 1986, The Popigai crater formed by the impact of common chondrite: Doklady Akademii Nauk SSSR, v. 286 p. $1476-1478$.

Miller, K., Fairbanks, R., and Mountain, G., 1987, Tertiary oxygen isotope synthesis, sea level history, and continental margin erosion: Paleoceanography, v. 2, p. 1-19, doi: 10.1029/PA002i001p00001.

Miller, K.G., Wright, J.D., and Fairbanks, R.G., 1991, Unlocking the Ice House: Oligocene-Miocene oxygen isotopes, eustasy, and margin erosion: Journal of Geophysical Research, v. 96, p. 6829-6848, doi: 10.1029/90JB02015.

Miller, K.G., Katz, M.E., and Berggren, W.A., 1992, Cenozoic deep-sea benthic foraminifera: A tale of three turnovers, in Takayanagi, Y., and Saito, T., eds., Studies in Benthic Foraminifera; Proceedings of the Fourth International Symposium on Benthic Foraminifera (Benthos '90): Sendai, Japan, Tokai University Press, p. 67-75.

Miller, K.G., Wright, J.D., and Browning, J.V., 2005, Visions of ice sheets in a greenhouse world: Marine Geology, v. 217, p. 215-231, doi: 10.1016/ j.margeo.2005.02.007.

Miller, K.G., Wright, J.D., Katz, M.E., Wade, B.S., Browning, J.V., and Rosenthal, Y., 2007, Passing a climate threshold at the Eocene-Oligocene transition: Antarctic ice takes the driver's seat, in Montanari, A., Koeberl, C., Coccioni, R., and Hilgen, F., eds., The Late Eocene Earth: Hot House, Ice House, and Impacts-Abstract with Program and Field Trip Guide: Ancona, Italy, Osservatorio Geologico di Coldigioco Frontale di Apiro, Geological Society of America Penrose Conference, p. 49-50.

Monechi, S., Buccianti, A., and Gardin, S., 2000, Biotic signals from nannoflora across the iridium anomaly in the Upper Eocene of the Massignano section: Evidence from statistical analysis: Marine Micropaleontology, v. 39, p. 219-237, doi: 10.1016/S0377-8398(00)00022-0.

Montanari, A., and Koeberl, C., 2000, Impact Stratigraphy-The Italian Record: Lecture Notes in Earth Sciences, v. 93, 364 p.

Montanari, A., Deino, A.L., Drake, R.E., Turrin, B.D., Depaolo, D.J., Odin, G.S., Curtis, G.H., Alvarez, W., and Bice, D.M., 1988, Radioisotopic dating of the Eocene-Oligocene boundary in the pelagic sequence of the Northern Apennines, in Premoli Silva, I., Coccioni, R., and A. Montanari, eds., The Eocene-Oligocene Boundary in the Marche-Umbria Basin (Italy): Aniballi, Ancona, International Subcommission on Paleogene Stratigraphy, Special Publication, p. 195-208.

Montanari, A., Asaro, F., Michel, H.V., and Kennett, J.P., 1993, Iridium anomalies of late Eocene age at Massignano (Italy), and ODP Site 689B (Maud Rise, Antarctic): Palaios, v. 8, p. 420-437, doi: 10.2307/3515017.

Montanari, A., Campo, A., and Farinella, P., 1998, Earth cratering record and impact energy flux in the last 150 Ma: Planetary and Space Science, v. 46, p. 271-281, doi: 10.1016/S0032-0633(97)00130-X.

Nocchi, M., Monechi, S., Coccioni, R., Madile, M., Monaco, P., Orlando, M., Parisi, G., and Premoli Silva, I., 1988a, The extinction of Hantkeninidae as a marker for recognizing the Eocene-Oligocene boundary: A proposal, in Premoli Silva, I., Coccioni, R., and Montanari, A., eds., The Eocene/ Oligocene Boundary in the Marche-Umbria Basin (Italy): Ancona, Italy, International Subcommission on Paleogene Stratigraphy, Special Publication, p. 249-252.

Nocchi, M., Parisi, G., Monaco, P., Monechi, S., and Madile, M., 1988b, Eocene and early Oligocene micropaleontology and paleoenvironments in SE Umbria, Italy: Palaeogeography, Palaeoclimatology, Palaeoecology, v. 67, p. 181-244, doi: 10.1016/0031-0182(88)90154-X.

Oberli, F., and Meier, M., 1991, Age of Eocene-Oligocene boundary in the Marche-Umbria basin, Italy, by high resolution U/Th-Pb dating: Terra Abstracts, v. 3, p. 286.

Obradovich, J.D., Snee, L., and Izett, G.A., 1989, Is there more than one glassy impact layer in the late Eocene?: Geological Society of America Abstracts with Programs, v. 21, no. 6, p. A134.

Odin, G.S., Montanari, A., Deino, A., Drake, R., Gruise, P., Kreuzer, H., and Rex, D.C., 1991, Reliability of volcano-sedimentary biotite ages around the Eocene/Oligocene boundary: Chemical Geology, v. 86, p. 203-224.

Okada, H., and Bukry, D., 1980, Supplementary modification and introduction of code numbers to the low-latitude coccolith biostratigraphic zonation (Bukry, 1973; 1975): Marine Micropaleontology, v. 5, p. 321-325, doi: 10.1016/0377-8398(80)90016-X.

Pagani, M., Zachos, J., Freeman, K.H., Bohaty, S., and Tipple, B., 2005, Marked change in atmospheric carbon dioxide concentrations during the Oligocene: Science, v. 309, p. 600-603, doi: 10.1126/science.1110063.

Pearson, P.N., and Palmer, M.R., 1999, Middle Eocene seawater pH and atmospheric carbon dioxide concentrations: Science, v. 284, p. 1824-1826, doi: 10.1126/science.284.5421.1824.

Pearson, P.N., Shackleton, N.J., and Hall, M.A., 1993, Stable isotope paleoecology of middle Eocene planktonic foraminifera and multi-species isotope stratigraphy, DSDP Site 523, South Atlantic: Journal of Foraminiferal Research, v. 23, p. 123-140.

Pearson, P.N., Shackleton, N.J., Weedon, G.P., and Hall, M.A., 1997, Multispecies planktonic foraminifer stable isotope stratigraphy through Oligocene/Miocene boundary climatic cycles, Site 926, in Shackleton, N.J., Curry, W.B., Richter, C., and Bralower, T.J., et al., Proceedings of the Ocean Drilling Program, Scientific Results, Volume 154: College Station, Texas, Ocean Drilling Program, p. 441-449.

Pearson, P.N., Ditchfield, P.W., Singano, S., Harcourt-Brown, K.G., Nicholas, C.J., Olsson, R.K., Shackleton, N.J., and Hall, M.A., 2001, Warm tropical sea surface temperatures in the Late Cretaceous and Eocene Epochs: Nature, v. 413, p. 481-487, doi: 10.1038/35097000.

Pearson, P.N., Olsson, R.K., Hemleben, C., Huber, B.T., and Berggren, W.A., 2006, Atlas of Eocene Planktonic Foraminifera: Cushman Foundation of Foraminiferal Research Special Publication 41, 514 p.

Persico, D., and Villa, G., 2004, Eocene-Oligocene calcareous nannofossils from Maud Rise and Kerguelen Plateau (Antarctica): Palaeoecological and palaeoceanographic implications: Marine Micropaleontology, v. 52, p. 153-179, doi: 10.1016/j.marmicro.2004.05.002.

Pierrard, O., Robin, E., Rocchia, R., and Montanari, A., 1998, Extraterrestrial Nirich spinel in Upper Eocene sediments from Massignano, Italy: Geology, v. 26, p. 307-310, doi: 10.1130/0091-7613(1998)026<0307:ENRSIU> 2.3.CO;2.

Poag, C.W., and Aubry, M.P., 1995, Upper Eocene impactites of the U.S. East Coast: Depositional origins, biostratigraphic framework and correlation: Palaios, v. 10, p. 16-43, doi: 10.2307/3515005.

Poag, C.W., Plescia, J.B., and Molzer, P.C., 2002, Ancient impact structures on modern continental shelves: The Chesapeake Bay, Montagnais, and Toms Canyon craters, Atlantic margin of North America: Deep-Sea Research, Part II, v. 49, p. 1081-1102, doi: 10.1016/S0967-0645(01)00144-8.

Poag, C.W., Mankinene, E., and Norris, R.D., 2003, Late Eocene impacts: Geologic record, correlation, and paleoenvironmental consequences, in Prothero, D.R., Yvany, L.C., and Nesbitt, E., eds., From Greenhouse to Icehouse: The Marine Eocene-Oligocene Transition: New York, Columbia University Press, p. 495-510.

Poag, C.W., Koeberl, C., and Reimold, W.U., 2004, The Chesapeake Bay crater-Geology and geophysics of a late Eocene submarine impact structure: Heidelberg, Germany, Springer, $522 \mathrm{p}$.

Poore, R.Z., and Matthews, R.K., 1984, Late Eocene-Oligocene oxygen and carbon isotope record from South Atlantic Ocean, Deep Sea Drilling Project Site 522, in Hsü, K.J., LaBrecque, J.L., et al., Initial Reports of the Deep Sea Drilling Project, Volume 73: Washington, D.C., U.S. Government Printing Office, p. 725-735. 
Premoli Silva, I., and Boersma, A., 1988, Atlantic Eocene planktonic foraminiferal biogeography and paleohydrographic indicators: Palaeogeography, Palaeoclimatology, Palaeoecology, v. 67, p. 315-356, doi: 10.1016/ 0031-0182(88)90159-9.

Premoli Silva, I., and Boersma, A., 1989, Atlantic Paleogene planktonic foraminiferal bioprovincial indices: Marine Micropaleontology, v. 14, p. 357371, doi: 10.1016/0377-8398(89)90019-4.

Premoli Silva, I., and Jenkins, D.G., 1993, Decision on the Eocene-Oligocene boundary stratotype: Episodes, v. 16, p. 379-382.

Prothero, D.R., 1994, The Eocene-Oligocene Transition-Paradise Lost: New York, Columbia University Press, $291 \mathrm{p}$.

Prothero, D.R., Ivany, L., and Nesbitt, E., 2003, From Greenhouse to Icehouse: The Marine Eocene-Oligocene Transition: New York, Columbia University Press, $541 \mathrm{p}$

Pusz, A.E., Miller, K.G., Wright, J.D., Browning, J.V., Wade, B.S., and Kent, D.V., 2006, Upper Eocene microtektites discovered in Alabama: A firstorder correlation to the GPTS: Geological Society of America Abstracts with Programs, v. 38, no. 7, p. 120.

Pusz, A.E., Miller, K.G., and Wright, J.D., 2007, Late Eocene impacts associated with a global carbon cycle perturbation, in Montanari, A., Koeberl, C., Coccioni, R., and Hilgen, F., eds., The Late Eocene Earth: Hot House, Ice House, and Impacts-Abstract with Program and Field Trip Guide: Ancona, Italy, Osservatorio Geologico di Coldigioco Frontale di Apiro, Geological Society of America Penrose Conference, p. 62-63.

Pusz, A.E., Miller, K.G., Wright, J.D., Katz, M.E., Cramer, B.S., and Kent, D.V., 2009, this volume, Stable isotopic response to late Eocene extraterrestrial impacts, in Koeberl, C., and Montanari, A., eds., The Late Eocene EarthHothouse, Icehouse, and Impacts: Geological Society of America Special Paper 452, doi: 10.1130/2009.2452(06).

Quilty, P.G., 2001, Late Eocene foraminifers and palaeoenvironment, Cascade Seamount, southwest Pacific Ocean: Implications for seamount subsidence and Australia-Antarctica Eocene correlation: Australian Journal of Earth Sciences, v. 48, p. 633-641.

Roberts, A.P., Bicknell, S.J., Byatt, J., Bohaty, S.M., Florindo, F., and Harwood, D.M., 2003, Magnetostratigraphic calibration of Southern Ocean diatom datums from the Eocene-Oligocene of Kerguelen Plateau (Ocean Drilling Program Sites 744 and 748), in Florindo, F., Cooper, A.K., and O'Brien, P.A., eds., Antarctic Cenozoic Palaeoenvironments: Geologic Record and Models: Palaeogeography, Palaeoclimatology, Palaeoecology, v. 198, p. $145-168$.

Sagnotti, L., Florindo, F., Verosub, K.L., Wilson, G.S., and Roberts, A.P., 1998, Environmental magnetic record of Antarctic palaeoclimate from EoceneOligocene glaciomarine sediments, Victoria Land margin: Geophysical Journal International, v. 134, p. 653-662, doi: 10.1046/j.1365-246x.1998 .00559.x.

Sepkoski, J.J., Jr., 1986, Phanerozoic overview of mass extinction, in Raup, D.M., and Jablonski, D., eds., Patterns and Processes in the History of Life: Berlin, Springer Verlag, p. 277-295.

Spezzaferri, S., 1994, Planktonic foraminiferal biostratigraphy and taxonomy of the Oligocene and Lower Miocene in the oceanic record: An overview: Paleontographia Italica, v. 81, 187 p.

Spezzaferri, S., 1995, Planktonic foraminiferal paleoclimatic implications across the Oligocene-Miocene transition in the oceanic record (Atlantic, Indian and South Pacific): Palaeogeography, Palaeoclimatology, Palaeoecology, v. 114, p. 43-74, doi: 10.1016/0031-0182(95)00076-X.
Spezzaferri, S., and Premoli Silva, I., 1991, Oligocene planktonic foraminiferal biostratigraphy and paleoclimatic interpretation from Hole 538A, DSDP Leg 77, Gulf of Mexico: Palaeogeography, Palaeoclimatology, Palaeoecology, v. 83, p. 217-263, doi: 10.1016/0031-0182(91)90080-B.

Spezzaferri, S., Basso, D., and Coccioni, R., 2002, Late Eocene planktonic foraminiferal response to an extraterrestrial impact at Massignano GSSP (northeastern Apennines, Italy): Journal of Foraminiferal Research, v. 32, p. 188-199, doi: 10.2113/0320188.

Stott, L.D., and Kennett, J.P., 1990, Antarctic Paleogene planktonic foraminifer biostratigraphy: ODP Leg 113, Sites 689 and 690, in Barker, P.F., Kennett, J.P., O'Connell, S., and Pisias, N.G., et al., Proceedings of the Ocean Drilling Program, Scientific Results, Volume 113: College Station, Texas, Ocean Drilling Program, p. 549-569.

Stott, L.D., Kennett, J.P., Shackleton, N.J., and Corfield, R.M., 1990, The evolution of Antarctic surface waters during the Paleogene: Inferences from the stable isotopic composition of planktonic foraminifers, ODP Leg 113, in Barker, P.F., Kennett, J.P., O'Connell, S., and Pisias, N.G., et al., Proceedings of the Ocean Drilling Program, Scientific Results, Volume 113: College Station, Texas, Ocean Drilling Program, p. 849-863.

Tagle, R., and Claeys, Ph., 2004, Comet or asteroid shower in the late Eocene?: Science, v. 305, p. 492, doi: 10.1126/science.1098481.

Toon, O.B., Zahnle, K., Turco, R.P., and Covey, C., 1994, Environmental perturbations caused by asteroid impacts, in Gehrels, T., ed., Hazards due to Comets and Asteroids: Tucson, University of Arizona Press, p. 791-826.

Tripati, A., Backman, J., Elderfield, H., and Ferretti, P., 2005, Eocene bipolar glaciation associated with global carbon cycle changes: Nature, v. 436, p. 341-346, doi: 10.1038/nature03874.

Van Eijden, A.J.M., and Ganssen, G.M., 1995, An Oligocene multi-species foraminiferal oxygen and carbon isotope record from ODP Hole 758A (Indian Ocean): Paleoceanographic and paleoecologic implications: Marine Micropaleontology, v. 25, p. 47-65, doi: 10.1016/0377-8398(94)00028-L.

Van Mourik, C., and Brinkhuis, H., 2005, The Massignano Eocene-Oligocene golden spike section revisited: Stratigraphy, v. 2, p. 13-30.

Vonhof, H.B., Smit, J., Brinkhuis, H., Montanari, A., and Nederbragt, A.J., 2000, Global cooling accelerated by early late Eocene impacts?: Geology, v. 28 , p. $687-690$, doi: 10.1130/0091-7613(2000)28<687:GCABEL $>$ 2.0.CO;2.

Wade, B.S., and Kroon, D., 2002, Middle Eocene regional climate instability: Evidence from the western North Atlantic: Geology, v. 30, p. 1011-1014, doi: 10.1130/0091-7613(2002)030<1011:MERCIE >2.0.CO;2.

Wade, B.S., and Palike, H., 2004, Oligocene climate dynamics: Paleoceanography, v. 19, p. PA4019, doi: 10.1029/2004PA001042.

Wei, W., and Wise, S.W., Jr., 1992, Eocene-Oligocene calcareous nannofossil magnetobiochronology of the Southern Ocean: Newsletters on Stratigraphy, v. 26, p. 119-132.

Zachos, J.C., Quinn, T.M., and Salamy, K.A., 1996, High resolution (104 years) deep sea foraminiferal stable isotope records of the EoceneOligocene climate transitions: Paleoceanography, v. 11, p. 251-266, doi: 10.1029/96PA00571.

Zachos, J.C., Pagani, M., Sloan, L., Thomas, E., and Billups, K., 2001, Trends, rhythms, and aberrations in global climate $65 \mathrm{Ma}$ to Present: Science, v. 292, p. 686-693, doi: 10.1126/science.1059412. 